\title{
A Reconstruction of the Federal Reserve Bank of St. Louis Adjusted Monetary Base and Reserves
}

\author{
Richard G. Anderson and Robert H. Rasche, with Jeffrey Loesel
}

T his paper summarizes the results of a benchmark reconstruction of the adjusted monetary base and adjusted bank reserves data of the Federal Reserve Bank of St. Louis. With this revision, these series include monthly figures from December 1917 to the present and biweekly figures from February 1984 to the present. ${ }^{1}$ During the reconstruction process, we reviewed the historical data used to measure the monetary base and the reserve adjustment magnitude (RAM), as well as the methods of construction for the series. Although all values of the series have changed, the principal changes are as follows:

- Monthly figures on both the adjusted monetary base and adjusted reserves now begin in December 1917. Previously, the adjusted monetary base began in 1936 and adjusted reserves began in 1980.2 Biweekly figures on the adjusted monetary base and adjusted reserves begin in February 1984, when the Federal Reserve shifted from lagged to nearcontemporaneous reserve accounting and lengthened reserve maintenance periods to 14 days from 7 days.

- Figures for the monetary (source) base have changed for January 1959 to December 1990. The revised figures are monthly averages of

The data in this article end as of September 2002.

2 Figures on the adjusted monetary base for 1917 to 1935 have been available on the Federal Reserve Bank of St. Louis Research Division web site ( < research.stlouisfed.org > ) since publication of Anderson and Rasche (1999). They have not previously been combined with later figures in a consistent format.

Richard G. Anderson is a vice president and economist and Robert $\mathrm{H}$ Rasche is a senior vice president and director of research at the Federal Reserve Bank of St. Louis. Jeffrey Loesel is a research associate at the Committee for Economic Development, in Washington, D.C. The reconstructed RAM for 1936-80 shown in this article largely was built by Jeffrey Loesel, then of Swarthmore College, during an internship at the Federal Reserve Bank of St. Louis. Marcela Williams, William Bock, and Michelle Meisch provided research assistance. Views expressed are those of the authors and not necessarily those of the Federal Reserve Bank of St. Louis, the Board of Governors of the Federal Reserve System, or the Committee for Economic Development.

(1) 2003, The Federal Reserve Bank of St. Louis. daily figures for currency in circulation and for deposits held by depository institutions at Federal Reserve Banks. Previous figures for this interval were pro rata monthly averages of 7-day or 14-day averages of daily figures. With this change, the monthly monetary base is measured consistently throughout its range as the average of daily figures. Differences between the revised and previous figures are small, typically less than $\$ 50$ million.

- Figures for the RAM from September 1935 to October 1980 have been changed to correct calculation errors. The changes are discussed in detail below.

- As of January 1994, the previously published RAM was replaced with the Anderson and Rasche (2001) adjustment that interprets a bank's implementation of a retail-deposit sweep program as being equivalent to a reduction in its statutory reserve requirement. This change increases the adjusted monetary base and adjusted reserves by approximately $\$ 18$ billion as of the reserve maintenance period that ended on September 30, 2002.

\section{THE ROLE OF THE MONETARY BASE IN MONETARY POLICY}

It is commonplace today for monetary policy analysis, both in theory and practice, to be conducted without reference to the monetary base or other monetary aggregates. ${ }^{3}$ Given this shift in monetary policy analysis, some readers of this article may question the value of reconstructing the St. Louis measure of the adjusted monetary base. We briefly address that question here. ${ }^{4}$

In a recent paper, Nelson (2002b) attributes the

\footnotetext{
3 The monetary base, or "outside money," continues to appear in theoretical structural models, e.g., Sargent (1987, Chap. I to IV, especially section IV.2). This dichotomy has led some economists to suggest that including money (and a central bank) is appropriate in structural models if the researcher wishes to examine changes in the economy's structure, but is unnecessary for near-term monetary policy in the currently popular small canonical models.

4 Interested readers may consult Nelson (2002a,b) for further analysis.
} 
omission of monetary aggregates, at least in part, to the intellectual influence of Taylor (1993) and subsequent related research. For near-term policymaking, Taylor's analysis succinctly combined policymakers' concerns regarding deviations of both inflation and gross domestic product (GDP) from desired target levels, while relegating money supply and demand to an invisible background role.

Recent analyses suggest two roles for the monetary base in policymaking. The first focuses on the long-run implications of monetary base growth for the price level and inflation rate. These authors argue that the truth of Milton Friedman's proposition"inflation is always and everywhere a monetary phenomenon"- does not depend on whether a monetary aggregate appears in the central bank's policy reaction function. Rather, at least in the theoretical long run when the effects of other shocks have played out, the inflation rate is determined by the growth rate of money because, absent such growth, inflation could not continue. It matters not at all in the long run whether policymakers target interest rates or monetary aggregates for, so long as their actions permit the necessary increases in the central bank's balance sheet, inflation will follow. Hence, observations on the monetary base may be useful in understanding ex post, if not ex ante, the effects of central bank actions. ${ }^{5}$

Although this long-run argument is compelling, the issue remains as to whether growth of the monetary base is useful for policymakers in the context of the current canonical model containing a forwardlooking IS (aggregate demand) equation, a pricesetting (aggregate supply) equation, and a Taylor-style policy rule. ${ }^{6}$ It is true that central banks achieve their interest rate targets by managing the quantity of base money held by the public. Yet, recent analyses suggest achieving policy targets by controlling the growth of the monetary base is more difficult and generally less successful than by controlling a short-term interest rate. Summarizing several recent studies, Nelson (2002b, p. 19), concurs: "But insofar

\footnotetext{
5 Allan Meltzer's recent history of the Federal Reserve System (Meltzer, 2003), for example, cites several episodes, such as 1920-21, in which economic activity was buffeted by the cross-currents of rising real interest rates and accelerating monetary base growth. Generally, the latter prevailed in bolstering economic expansion. The best of such examples seems to be for the gold standard period, as suggested by Nelson (2002b, footnote 32). Meltzer's analysis uses the St. Louis adjusted monetary base figures developed in Anderson and Rasche (1999)

6 See, for example, McCallum (2001).
}

as a key message... is that the control of inflation around its steady-state value can be accomplished by a monetary policy framework that does not respond explicitly to monetary aggregates, I would not disagree." McCallum (2001), after formally testing the role of money within his canonical model, reaches the same conclusion. McCallum's result also suggests that, even in the long run, policymakers may benefit little from monitoring growth of the monetary base: Because the steady-state inflation target is both arbitrary (in the model) and a monetary phenomenon, the same policy mechanism that allows policymakers to achieve their specified inflation target also allows them, by changing growth of the monetary base, to achieve an alternative inflation target.

Overall, therefore, the usefulness to policymakers of monetary base growth as an indicator of the stance of monetary policy remains an open question. Further, the reconstructed series presented in this article likely will be of value to researchers exploring linkages between Taylor-style policy rules and monetary aggregates.

Finally, Nelson (2002a,b) suggests that growth of the monetary base may be valuable as a proxy for, or indicator of, the workings of a broad (but largely hidden) monetary transmission mechanism of the Brunner-Meltzer-Friedman-Schwartz variety that emphasizes that monetary policy actions induce substitution by households and firms among a large number of assets. ${ }^{7}$ Nelson (2002b) emphasizes that the omission of money from the aggregate demand equation is not a specification error (because the transmission mechanism never suggested it should be there anyway), but the omission of yields other than the short-term policy rate is a serious error. Indeed, statistical explanatory power for monetary base growth perhaps is due to the omission of this broader set of yields because the omitted terms likely are highly correlated with changes in the growth rate of the monetary base. ${ }^{8}$

The recent nearness-to-zero of policy-target rates in the United States and Japan has further stimulated discussion of the role of the monetary

\footnotetext{
7 See Brunner and Meltzer $(1963,1968)$ and Friedman and Schwartz $(1963,1982)$

8 Meltzer (2001a) and Nelson (2002a) find that real monetary base growth has significant in-sample explanatory power for growth of U.S. real consumption and output, respectively, when a long-term nominal interest rate is included and prices are sticky. Nelson's analysis uses the St. Louis measure of the domestically held adjusted monetary base developed in Anderson and Rasche (2000). Nelson also finds a similar result for the United Kingdom.
} 
base as a policy indicator. ${ }^{9}$ McCallum (2003), for example, has emphasized that many low-default-risk assets may become cash-equivalents at near-zero yields and that the central bank may need to purchase unusually large quantities of such assetsthat is, boost substantially monetary base growth - if it wishes to affect spending by inducing portfolio substitution into equity, foreign currencies, or various higher-risk private-sector debt. Since the nominal policy-target interest rate ceases to move once it settles near zero, growth of the monetary base may be the most suitable policy indicator available to the central bank.

\section{THE MONETARY (SOURCE) BASE}

The monetary base is defined as those liabilities of the monetary authorities that households and firms use as media of exchange and that depository institutions use to satisfy statutory reserve requirements and to settle interbank debts. ${ }^{10}$ In the United States, this includes currency (including coin) held outside the Treasury and the Federal Reserve Banks (referred to as currency in circulation) plus deposits held by depository institutions at the Federal Reserve Banks. The demand by the private sector for these liabilities gives the Federal Reserve leverage to affect money market interest rates.

In our reconstruction, all monthly and biweekly figures for the monetary base are averages of daily figures. Previously, some monthly figures were averages of daily figures (before 1959 and after early 1989), but some were not: Monthly figures from 1959 through early 1989 were pro rata monthly averages of 7-day and, after January 1984, 14-day averages of daily figures. This change to the St. Louis measure of the monetary base removes a measurement inconsistency and makes our monetary base figures replicable from published data. ${ }^{11}$ With respect to its impact on the time-series behavior of

\footnotetext{
9 See McCallum (1993, 2003) and Meltzer (2001b).

${ }^{10}$ Throughout, we use the term monetary base to refer to the same concept that frequently in the literature has been referred to as the monetary source base or the source base. Except for occasional emphasis, we omit the word "source" from the text.

11

The following publications are from the Board of Governors of the Federal Reserve System: For months prior to January 1991, figures are from Banking and Monetary Statistics (1943 [1976], 1976) and various issues of the Annual Statistical Digest. Beginning January 1991, figures are from the weekly H.4.1 data release and the Federal Reserve Bulletin table "Reserves of Depository Institutions and Reserve Bank Credit." In the January 2003 issue of the Bulletin, this is Table 1.11, p. A5. Additional details regarding data sources are contained in the appendix to this article.
}

the monetary base, this change is largely a technical revision. From January 1959 through December 1990 , the mean levels of the revised and previous figures are $\$ 129.307$ billion and $\$ 129.351$ billion, respectively, with standard deviations of $\$ 76.095$ billion and $\$ 76.068$ billion. The two series' average continuously compounded growth rates are the same (because the series begin and end with the same figures), while their standard deviations differ only slightly, at 11.867 percent for the revised series and 11.834 for the previous series.

One problem, likely irresolvable, remains in our measurement of the deposit component of the monetary base: So far as we are aware, there are no published monthly average figures for deposits held by depository institutions at the Federal Reserve Banks. Conceptually, this component of the monetary base could be measured easily because these deposits are liabilities of the Federal Reserve Banks and, hence, appear on Reserve Bank balance sheets. Unfortunately, at least for measurement of the monetary base, balance sheet figures are hard to come by: Since its creation, the Federal Reserve has followed the commercial banking industry's practice of publishing balance sheet figures only for selected days, most often Wednesdays and the last business day of the month. ${ }^{12}$ As a proxy for these unavailable deposit figures, we measure the deposit component of the monetary base by the sum of "reserve balances with Federal Reserve Banks" plus, beginning January 1981, "service-related balances and adjustments." 13 Although this proxy satisfies our criterion to provide a monthly average of daily figures, it differs from our ideal deposit figure by including "as of" accounting adjustments that compensate depository institutions for the time-value of any inappropriate credits or debits to their Federal Reserve deposit accounts, including certain delays in check clearing.

We conducted two experiments to measure the adequacy of our proxy. Both experiments suggested that the proxy is an acceptable measure of deposits held by depository institutions at the Federal Reserve. First, from the Federal Reserve Board's microfilm

\footnotetext{
12 See the January 2003 issue of the Federal Reserve Bulletin, Table 1.18, p. A10, "Federal Reserve Banks: Condition and Note Statements." Deposits held by depository institutions at Federal Reserve Banks are shown in line 25 .

${ }^{13}$ See the January 2003 issue of the Federal Reserve Bulletin, Table 1.11, p. A5, "Reserves of Depository Institutions and Reserve Bank Credit." Reserve balances are shown in line 25 and service-related balances are shown in line 22 .
} 
archive, we retrieved a sample of several months of unpublished daily balance sheets for the Reserve Banks prior to 1980. We compared aggregate monthly averages of these figures with published monthly figures of the average daily reserve balances held by member banks at the Federal Reserve. There were only minor differences. From this experiment, we concluded that the considerable cost to retrieve additional figures likely would far exceed the value of the increase in measurement accuracy. In a second experiment, we obtained unpublished figures from the Board of Governors, beginning January 1986, on the monthly averages of aggregate daily deposits held at Federal Reserve Banks. We found only minor differences between these figures and our proxy.

In our opinion, as-of adjustments should be excluded from the monetary base because these amounts cannot be used to settle interbank debits, nor can they be loaned to other depositories in the money market. But the argument is not unambiguous: As-of adjustments can be applied to reduce the amount of deposits that a depository institution must hold at the Federal Reserve to satisfy its required reserves. In practice the issue is settled by data availability. In addition, our experiments suggest that as-of adjustments tend to be both small enough in size and random enough in occurrence that the measurement error in our proxy, relative to actual balance-sheet figures of deposits at the Federal Reserve Banks, is minor.

\section{ADJUSTING FOR THE EFFECTS OF CHANGES IN STATUTORY RESERVE REQUIREMENTS}

Because changes in statutory reserve requirements affect depository institutions' demand for base money, it is necessary to adjust the monetary base and total reserves for the effects of these changes before the figures can be used for economic analysis. In the St. Louis series, this is accomplished by adding to each series the reserve adjustment magnitude, or RAM. ${ }^{14}$ RAM measures how differences in statutory reserve requirements between those in effect on the date of each observation, denoted $t$, and those in effect during a specific base period,

\footnotetext{
14 For previous discussions of the concept of RAM as used here, see Burger and Rasche (1977), Tatom (1980), and Anderson and Rasche (1996, 1999, 2001).

15 The base-period statutory reserve requirements for RAM(1991) are the requirements applicable to the reserve maintenance period that ended Wednesday, January 9, 1991. The requirements during this period
}

denoted $\tau$, affect monetary base demand. ${ }^{15}$ If the reserve-requirement regime in effect during the current period, $t$, is the same as the regime during the base period, $\tau$, then $R A M_{t}=0$.

Currently, RAM has five segments, referred to as RAM(1922), RAM(1935), RAM(1972), RAM(1975), and RAM(1991). Each segment corresponds to a given structure, or regime, of reserve requirements. The name of each segment refers to the year of its base-period reserve-requirement regime: July 1922, September 1935, December 1972, January 1975, and January 1991, respectively. When a major change occurs in reserve requirements, the previous RAM segment ends and a new RAM segment begins.

The method used to calculate each segment of RAM depends on data availability. Prior to September 1968, values are calculated from aggregate monthly figures. From September 1968 through October 1980 , values are calculated from aggregate weekly figures. ${ }^{16}$ Beginning October 1980, values are calculated from the weekly figures of individual banks, as discussed in Anderson and Rasche (1996, 2001). Prior to November 1980, the calculation includes all Federal Reserve member banks. From November 1980 through December 1990, the calculation includes only those depository institutions with net transaction deposits greater than the low-reserve tranche and required reserves greater than their vault cash. ${ }^{17}$ Beginning January 1991, the calcula-

included a low-reserve tranche of $\$ 41.1$ million, a reserve-exemption amount of $\$ 3.4$ million, a 12 percent reserve-requirement ratio on net transaction deposits in excess of the low-reserve tranche, a 3 percent ratio on net transaction deposits within the tranche, and a zero percent ratio on net transaction deposits within the reserve-exemption amount and on other deposits and borrowings. Because reserve requirements did not change during 1991, RAM(1991) equals zero for maintenance periods through the period that ended December 25, 1991. RAM(1991) becomes positive for the reserve maintenance period beginning December 26, 1991, because, effective on that date, the low-reserve tranche and reserve-exemption amounts increased to $\$ 42.2$ million and $\$ 3.6$ million, respectively.

16 Most of these figures are from the Board of Governor's published H.7 release. Some are unpublished figures from the archives of the Research Division of the Federal Reserve Bank of St. Louis.

${ }^{17}$ Since 1981, RAM has become more complicated: RAM cannot be calculated simply by comparing (subtracting) required reserves under the current-period and base-period statutory reserve-requirement regimes. If reserve requirements in a given period are lower than those in the specified base period, a depository institution that was constrained by the base-period regime might not be constrained by the current regime. If in this case, as seems reasonable, the amount of reserves held during the current period is less than the amount held during the base period, RAM must be calculated so as to measure only the portion of that reduction that is due to the lower reserve requirements (in general, this is less than the total reduction in required reserves). For details, see Anderson and Rasche (2001, pp. 57-58). 
tions include only those depository institutions with net transaction deposits greater than the $\$ 135$ million threshold estimated in Anderson and Rasche (1996).

For this analysis, we collected all available (published and unpublished) historical data relating to deposits and required reserves of member banks prior to $1980 .{ }^{18}$ Based on these figures, we reconstructed RAM for the period August 1935 through October 1980. Our efforts changed many of the figures in RAM(1935), RAM(1972), and RAM(1975) ${ }^{19}$ :

- RAM(1935) has been changed to correct an error that caused it, for dates prior to September 1968, to display one month prematurely the effects of changes in reserverequirement ratios. The originally intended calculation, which sought to adjust for the delayed availability of aggregate deposit figures relative to figures on the monetary base and bank reserves, was

$\operatorname{RAM}(1935)_{t}=\sum_{j}\left(r_{j, \tau}-r_{j, t}\right) D_{j, t-1}$

where $j$ indexes the type of deposit and $r_{j, t}$ and $r_{j, \tau}$, respectively, are the current and base period ( $\tau=$ September 1935) reserve-requirement ratios. During our reconstruction, we found that the currently published series inadvertently had been calculated as $\operatorname{RAM}(1935)_{t}=\sum_{j}\left(r_{j, \tau}-r_{j, t+1}\right) D_{j, t}$, which displays one month prematurely the effect of changes in reserve-requirement ratios. Our new calculation, which supercedes previously published figures, contains no lags:

$R A M(1935)_{t}=\sum_{j}\left(r_{j, \tau}-r_{j, t}\right) D_{j, t}$.

So far as we have been able to determine, values of RAM(1935) for months beginning September 1968, which were calculated from weekly deposit figures, were not affected by this error. ${ }^{20}$

\footnotetext{
${ }^{18}$ In a previous article, we examined, in detail, historical data beginning November 1980; see Anderson and Rasche (1996). For this study, some data are from published sources and some are from unpublished archival records of the Federal Reserve Bank of St. Louis.

${ }^{19}$ The first segment, RAM(1922), is unchanged from the figures in Anderson and Rasche (1999)

${ }^{20}$ Values of RAM(1935) for dates after August 1968 differ slightly from previously published figures because they have been recalculated from aggregate deposit and required-reserve figures.
}

For the period 1935-49, this correction removes the large negative monthly growthrate spikes in the adjusted monetary base that are apparent in the third-row panel of the left column in Figure 2 of Anderson and Rasche (1999). The correction does not change, however, our conclusion in that analysis that no regular (stable, estimable) seasonal pattern is apparent between 1933 and 1949.

- RAM(1972) and RAM(1975) have been changed to correct an error that caused their base-period values to differ from zero. The error is due to an incorrect treatment of the supplemental and marginal reserve requirements introduced by the Board of Governors in 1969 (see Table 1). To illustrate the issue, we need to be precise regarding differences between the Federal Reserve reserve-requirements regimes before and after 1969. For dates prior to 1969 , member banks' aggregate required reserves were well-approximated by a linear function of their aggregate deposits,

$R R_{t}=\sum_{j} r_{j, t} D_{j, t}$.

In addition, member banks changed their holdings of base money approximately dollar-for-dollar with changes in required reserves. Hence, if we let

$$
R R_{t, \tau}=\sum_{j} r_{j, \tau} D_{j, t}
$$

measure the (counterfactual) amount of base money that these banks would have held during period $t$ if the reserve-requirement regime of period $\tau$ had been in effect, the RAM adjustment for period $t$ relative to period $\tau$ is

$$
R A M_{t}=R R_{t, \tau}-R R_{t}=\sum_{j}\left(r_{j, \tau}-r_{j, t}\right) D_{j, t} .
$$

Due to their complexity, the supplemental and marginal reserve requirements introduced in 1969 are not well-approximated by linear functions of aggregate deposits. Hence, we add a second term to RAM:

$$
\begin{aligned}
& R R_{t}=R R_{t}^{\text {deposits }}+R R_{t}^{\text {other }}=\sum_{j} r_{j, t} D_{j, t}+R R_{t}^{\text {other }} \\
& R R_{t, \tau}=R R_{t, \tau}^{\text {deposits }}+R R_{t, \tau}^{\text {other }}=\sum_{j} r_{j, \tau} D_{j, t}+R R_{t, \tau}^{\text {other }} .
\end{aligned}
$$

Then, RAM is 


\section{Table 1}

\section{Supplemental and Marginal Reserve Requirements, 1969-80}

Date

October 1969-August 1978

June 1973-December 1974

\section{Change in requirements}

Effective with the reserve maintenance period beginning October 16, 1969, member banks were required (Federal Reserve Regulation $M$ ) to maintain reserves on net Eurocurrency liabilities, that is, the sum of balances due to related foreign offices plus certain loans by related foreign branches to U.S. residents and (Regulation D) on borrowings by domestic banking offices from foreign banks.

Ratios:

- 10 percent effective October 16, 1969;

- increased to 20 percent, January 7, 1971;

- reduced to 8 percent, June 21, 1973;

- reduced to 4 percent, May 22, 1975;

- reduced to zero, August 24, 1978.

Originally, the requirements applied only to amounts above a reserve-free base amount. The base amount for loans by related foreign offices to U.S. residents was eliminated on June 21, 1973, and the other base amounts were gradually phased out by March 14, 1974 (thereby increasing the total requirement). Smaller loans and loans at banks with smaller aggregate amounts were excluded.

“From June 21, 1973, through Dec. 11, 1974, member banks, except as noted below, were subject to a marginal reserve requirement against increases in the aggregate of the following types of obligations: (a) outstanding time deposits of $\$ 100,000$ or more, (b) outstanding funds obtained by the bank through issuance by a bank's affiliate of obligations subject to the existing reserve requirements on time deposits, and (c) beginning July 12, 1973, funds from sales of finance bills. For the period June 21 through August 24, 1973, (a) included only singlematurity time deposits. The requirement applied to balances above a specified base, but was not applicable to banks having obligations of these types aggregating less than \$10 million. Including the basic requirement (5 per cent during the entire period), requirements were: 8 per cent for (a) and (b) from June 21 through October 3, 1973, and for (c) from July 12 through October 3, 1973; 11 per cent from October 4 through December 26, 1973; and 8 per cent from December 27, 1973, through September 18, 1974. Beginning September 19, the 8 per cent requirement applied to only those obligations in (a), (b) and (c) with initial maturities of less than 120 days, and effective December 12, 1974, the remaining marginal reserve on this type of obligation issued to mature in less than 4 months was removed." (Annual Report of the Board of Governors of the Federal Reserve System for 1976, Table 13)

August 1978
For the maintenance period beginning August 24, 1978, requirements were

- reduced to zero percent from 4 percent on net Eurocurrency liabilities of domestic banks to their own foreign branches;

- reduced to zero percent from 1 percent on deposits that foreign branches of domestic banks lend to U.S. residents;

- reduced to zero percent from 4 percent on borrowings of domestic banks from unrelated banks abroad. 


\section{Table 1, cont'd}

\section{Supplemental and Marginal Reserve Requirements, 1969-80}

Date

November 1978

November 1978

October 1979

April 1980

June 1980

July 1980

\section{Change in requirements}

Effective with the maintenance period beginning November 2, 1978, a 2 percent supplementary reserve requirement on time deposits of $\$ 100,000$ or more, obligations of affiliates, and ineligible acceptances was imposed.

Effective with the maintenance period beginning November 16, 1978, domestic deposits of Edge corporations became subject to the same reserve requirements as deposits of member banks. Previously, all deposits of Edge corporations were subject to a 10 percent requirement.

Effective for member banks with the maintenance period beginning October 25, 1979 , and for U.S. agencies and branches of foreign banks for the period beginning November 8, 1979 (note that the latter institutions previously did not hold deposits at the Federal Reserve), an 8 percent marginal reserve requirement was imposed on increases, above a base amount, in "managed liabilities" at member banks, Edge corporations, and U.S. agencies and branches of foreign banks. These liabilities are those that were actively being used to finance rapid expansion in bank credit, including large time deposits with maturities of less than a year, Eurodollar borrowings, repurchase agreements against U.S. government and federal agency securities, and federal funds borrowings from nonmember institutions.

Following this change, the total reserve requirement for large time deposits included a basic requirement of 1 to 6 percent, depending on maturity, plus a 2 percent supplemental reserve requirement (November 1978), plus an 8 percent marginal requirement.

For Eurodollar borrowings, loans made by foreign offices of member banks to U.S. residents, and for assets sold by member banks, Edge corporations, and U.S. branches and agencies to related foreign offices, the marginal requirement increased to 8 percent from zero percent.

For repurchase agreements against U.S. government and federal agency securities, the marginal requirement increased to 8 percent from zero percent.

Effective with the maintenance period beginning April 3, 1980, the marginal reserve-requirement ratio, as implemented October 1979, was increased to 10 percent from 8 percent.

Effective with the maintenance period beginning June 12, 1980, the marginal reserve-requirement ratio, as implemented October 1979, was reduced to 5 percent from 10 percent.

Effective with the maintenance period beginning July 24, 1980, the marginal reserve-requirement ratio, as implemented October 1979, was reduced to zero percent from 5 percent; and the supplementary reserve requirement on large time deposits, implemented November 1978, was reduced to zero percent from 2 percent.

SOURCE: Compiled by the authors from the Federal Reserve Bulletin (various issues) and the Annual Report of the Board of Governors of the Federal Reserve System (various issues). 


$$
\begin{aligned}
R A M_{t} & =\left(R R_{t, \tau}^{\text {deposits }}-R R_{t}^{\text {deposits }}\right)+\left(R R_{t, \tau}^{\text {other }}-R R_{t}^{\text {other }}\right) \\
& =\sum_{j}\left(r_{j, \tau}-r_{j, t}\right) D_{j, t}+\left(R R_{t, \tau}^{\text {other }}-R R_{t}^{\text {other }}\right) \\
& =R A M_{t}^{\text {deposits }}+R A M_{t}^{\text {other }}
\end{aligned}
$$

Previously published values for RAM(1972) and RAM(1975) were calculated as

$$
\begin{aligned}
R A M_{t} & =\sum_{j} r_{j, \tau} D_{j, t}-\sum_{j} r_{j, t} D_{j, t}-R R_{t}^{\text {other }} \\
& =R A M_{t}^{\text {deposits }}+\left(R A M_{t}^{\text {other }}-R R_{t, \tau}^{\text {other }}\right),
\end{aligned}
$$

which is correct only if $R R_{t, \tau}^{\text {other }}=0$, that is, if the amount of base money held by banks to satisfy supplementary and marginal requirements was zero during the base period, $\tau$.

\section{CHAINING THE ADJUSTED MONETARY BASE}

The complete time series of observations for the adjusted monetary base and adjusted reserves, from 1917 to the present, are chained indices with splices at four dates (August 1935, December 1972, January 1975 , and October 1980) corresponding to the segments of RAM. For the adjusted monetary base, the splice factors are as follows:

$$
\begin{aligned}
& f_{1}=\frac{M B_{1935: 8}+R A M(1935)_{1935: 8}}{M B_{1935: 8}+R A M(1922)_{1935: 8}} \\
& f_{2}=\frac{M B_{1972: 12}+R A M(1972)_{1972: 12}}{M B_{1972: 12}+R A M(1935)_{1972: 12}} \\
& f_{3}=\frac{M B_{1975: 1}+R A M(1975)_{1975: 1}}{M B_{1975: 1}+R A M(1972)_{1975: 1}} \\
& f_{4}=\frac{M B_{1980: 10}+R A M(1991)_{1980: 10}}{M B_{1980: 10}+R A M(1975)_{1980: 10}} .
\end{aligned}
$$

Then, the adjusted monetary base is calculated as

$$
\begin{array}{ll}
A M B_{t} & \\
=\prod_{i=1}^{4} f_{i}^{*}\left(M B_{t}+R A M(1922)_{t}\right), & t=1917: 12, \ldots, 1935: 8 \\
=\prod_{i=2}^{4} f_{i}^{*}\left(M B_{t}+R A M(1935)_{t}\right), & t=1935: 8, \ldots, 1972: 12 \\
=\prod_{i=3}^{4} f_{i}^{*}\left(M B_{t}+R A M(1972)_{t}\right), & t=1972: 12, \ldots, 1975: 1 \\
=f_{4}^{*}\left(M B_{t}+R A M(1975)_{t}\right), & t=1975: 1, \ldots, 1980: 10 \\
=\left(M B_{t}+R A M(1991)_{t}\right), & t=1980: 10, \ldots
\end{array}
$$

For the adjusted monetary base, the splice factors $f_{1}, f_{2}, f_{3}, f_{4}$ have values of $0.99677,1.03187$,

1.00564 , and 0.85671 , respectively.

\section{TOTAL (DEPOSITORY INSTITUTION) RESERVES}

The Federal Reserve Bank of St. Louis measure of adjusted reserves is a chain index that includes the same RAM adjustment as the adjusted monetary base and, hence, is constructed in five segments corresponding to RAM(1922), RAM(1935), RAM (1972), RAM(1975), and RAM(1991).

Each segment of adjusted reserves equals the sum of the monetary (source) base, plus the appropriate RAM, minus the currency component of M1.21 For dates beginning January 1959, our measure of currency is the Federal Reserve Board's published figures. For January 1947 through December 1958, our figures are from the Board's Banking and Monetary Statistics, 1941-1970 (1976, Table 1.1B, p. 20). For December 1917 through December 1946, our figures are from Friedman and Schwartz (1970, Table 1, pp. 16-37).22

For adjusted reserves, the values of the splice factors $f_{1}, f_{2}, f_{3}, f_{4}$ are $0.99421,1.09117,1.01506$, and 0.53626 .

The same procedure could be used to construct a nonborrowed or free reserves aggregate, although we have not done so.

\section{ADJUSTMENTS FOR SEASONAL VARIATION}

Seasonal adjustment of the adjusted monetary base and adjusted total reserves follows the procedure outlined in Anderson and Rasche (1999). We do not revisit figures prior to 1950 because our revisions to RAM(1935), RAM(1972), and RAM(1975) do not change the seasonal variation of the adjusted monetary base. In our final "seasonally adjusted" series, we include figures for 1918-32 based on the

\footnotetext{
21 See the January 2003 issue of the Federal Reserve Bulletin, Table 1.21, p. A13, "Money Stock Measures." The currency component of M1 is shown on line 4 . Note that this measure of currency does not include travelers checks (see footnotes 3 and 4 to Table 1.21).

22 Figures for early years regarding the currency component of M1, and hence total bank reserves, contain significant judgmental estimation and should be used with caution. Currently and in historical series, the currency component of M1 is calculated by subtracting depository institutions' aggregate vault cash from aggregate currency in circulation. Although good-quality monthly figures on currency in circulation are available even prior to our starting date of December 1917, prior to implementation of the Monetary Control Act in 1980 monthly figures on vault cash must be estimated from bank call reports. For discussion of periods prior to 1970, see Friedman and Schwartz (1970, Chap. 12); for discussion of later periods, see Anderson and Kavajecz (1994).
} 
seasonal patterns identified in Anderson and Rasche (1999) and, as in that article, include for 1933-49 the seasonally unadjusted figures.

For the period beginning January 1950, we seasonally adjust the adjusted monetary base and adjusted reserves in a two-step procedure using the Bureau of the Census X-12 seasonal adjustment software. The Census X-12 software package consists of two components. The first component is a flexible Box-Jenkins ARIMA modeling package, and the second component is an enhanced version of the classic Census X-11 seasonal-factor estimation program.

In our first step, we develop an ARIMA model with intervention terms. The X-12 software permits a variety of flexible intervention terms, as shown in the first section of Table 2 . Some of the terms are simple 0-1 dummy variables, while others, such as the "ramp" and "temporary change" adjustment, are more complex. 23 The fitted model's intervention terms are used to remove outliers from the data prior to estimation of seasonal factors; this is done by means of the enhanced X-11 routines. In addition, the fitted model is used to forecast the series 24 months into the future prior to estimation with $\mathrm{X}-11 .{ }^{24}$ In the second step, we use the X-11 algorithms to estimate seasonal-adjustment factors from the outlier-adjusted data. Our final estimated ARIMA models are shown in Table 2 . The estimated seasonal factors are shown in Figure 1.

We focus special attention on two recent periods. The first, during late 1999 and early 2000, is due to the Y2K buildup of precautionary currency holdings. The second, during September 2001, is due to interruptions in the payments system following the New York City terrorist attacks. For the first, we include two ramp intervention terms in

\footnotetext{
23 The "ramp" intervention term fits a straight line between two points. The "temporary change" term permits an immediate shift in the series followed by decay back to the initial level. The shapes of X-12 intervention variables are discussed in Findley et al. (1998), which also discusses issues related to test size and critical values for the sequential testing of non-nested alternative intervention terms. Estimation in X-12 is by exact maximum likelihood.

${ }^{24}$ The X-11 algorithms are two-sided moving-average filters. Extensive research has shown that the quality of estimated seasonal adjustment factors for most economic time series is improved if the time series is extended forward prior to estimation with X-11 so as to avoid folding the X-11 filters at the end of the series. The ARIMA model forecasts are used for no other purpose. Most often, such forecasts for X-11 estimation are produced by an ARIMA model because the family of datagenerating processes for which X-11 provides accurate estimates of the seasonal patterns is the same family for which a Box-Jenkins ARIMA model can closely approximate the data-generating process.
}

the ARIMA models for the adjusted monetary base and for adjusted reserves; one spans August to December 1999, and the other spans December 1999 to February 2000. ${ }^{25}$ For September 11, 2001, we include an additive outlier in the model for the adjusted monetary base (other intervention terms were rejected) and both a temporary change (for September) and a level shift (October) in the model for reserves. These variables, confirmed by the statistical results, are suggested by time-series plots of total reserves and of the ratio of reserves to transaction deposits (not shown here), which suggest that banks' aggregate holdings of base money increased and remained at an elevated level after September 11, 2001.

In addition to our a priori variables, we allowed the automatic model selection algorithms in the X-12 package to suggest additional intervention variables. The algorithms added seven intervention terms to the model for the monetary base (three of which are related to Y2K and September 11, 2001) and 21 terms to the model for adjusted reserves (including three related to Y2K and September 11, 2001). The large number of intervention terms selected for the reserves model likely reflects the relatively higher volatility of reserves. For both series, the final ARIMA model contains a seasonal and nonseasonal difference, a nonseasonal AR polynomial, and a seasonal MA polynomial. The reserves model also contains a nonseasonal MA polynomial. ${ }^{26}$

Seasonal-adjustment factors for biweekly (reserve maintenance period) data, beginning February 1984, are obtained by an iterative procedure. In this method, a set of initial estimates of biweekly seasonally adjusted levels of the adjusted base is obtained with polynomial interpolation between observations on seasonally adjusted monthly levels. An initial set of seasonal adjustment factors are obtained by dividing actual not-seasonally-adjusted biweekly levels by these initial estimated seasonally adjusted levels. This process is iterated so that the final seasonally adjusted biweekly levels average to the seasonally adjusted monthly levels for historical data. ${ }^{27}$

\footnotetext{
25 Although our two ramp adjustments resemble a linear spline, we do not force the end of the first segment to be attached to the beginning of the second segment.

${ }^{26}$ In our estimation, we do not include variables for the shift from lagged to near-contemporaneous reserve accounting in February 1984 and the shift from contemporaneous to lagged reserve accounting in July 1998.

${ }^{27}$ For future periods, we project separately the future monthly and biweekly seasonal adjustment factors.
} 


\section{Table 2}

ARIMA Models Used in Seasonal Adjustment of the Adjusted Monetary Base and Adjusted Reserves

Intervention variables used in ARIMA models

$A O$ : Additive outlier at date $t_{0}$

$$
\begin{aligned}
& A O_{t}^{\left(t_{0}\right)}=\left\{\begin{array}{lll}
1 & \text { for } & t=t_{0} \\
0 & \text { for } & t \neq t_{0}
\end{array}\right. \\
& L S_{t}^{\left(t_{0}\right)}=\left\{\begin{array}{lll}
-1 & \text { for } & t<t_{0} \\
0 & \text { for } & t \geq t_{0}
\end{array}\right.
\end{aligned}
$$

$L S$ : Level shift at date $t_{0}$

TC: Temporary change at date $t_{0}$, with decay at rate $\alpha$ back to the previous level $(0<\alpha<1)$

$$
T C_{t}^{\left(t_{0}\right)}=\left\{\begin{array}{lll}
0 & \text { for } & t<t_{0} \\
\alpha^{t-t_{0}} & \text { for } & t \geq t_{0}
\end{array}\right.
$$

$R P$ : Ramp between date $t_{0}$ and date $t_{1}$

$$
R P_{t}^{\left(t_{0}, t_{1}\right)}=\left\{\begin{array}{lll}
-1 & \text { for } t \leq t_{0} \\
\left(t-t_{0}\right) /\left(t_{1}-t_{0}\right) & \text { for } t_{0}<t<t_{1} \\
0 & \text { for } t \geq t_{1}
\end{array}\right.
$$

A. Model for the adjusted monetary base

$$
\left(1-\phi_{1} B^{3}-\phi_{2} B^{6}-\phi_{3} B^{9}\right)\left(1-B^{12}\right)(1-B) A M B_{t}=C+\sum_{j} I_{j, t}+\left(1+\theta B^{12}\right) \varepsilon_{t}
$$

Intervention variables (I)

Constant
TC1981.Jan
RP1999.Sep-1999.Dec
TC1999.Dec
RP1999.Dec-2000.Feb
TC2000.Jan
TC2001.Sep
TC1952.Apr
AO1954.Jan
AO1975.May
$\varphi_{1}$
$\varphi_{2}$
$\varphi_{3}$
$\theta$

Parameter estimate

$\begin{array}{rl}0.0001 & 0.00292 \\ -0.0104 & 0.00236 \\ 0.0143 & 0.00001 \\ 0.0193 & 0.00387 \\ -0.0249 & 0.00281 \\ 0.0133 & 0.00347 \\ 0.0347 & 0.00327 \\ -0.0103 & 0.00297 \\ 0.0080 & 0.00229 \\ -0.0091 & 0.00227 \\ 0.2247 & 0.04059 \\ 0.1890 & 0.04152 \\ 0.0489 & 0.04096 \\ 0.6672 & 0.03090\end{array}$




\section{Table 2, cont'd}

ARIMA Models Used in Seasonal Adjustment of the Adjusted Monetary Base and Adjusted Reserves

B. Adjusted reserves

$$
\left(1-\phi_{1} B^{3}-\phi_{2} B^{6}\right)\left(1-B^{12}\right)(1-B) A M B_{t}=C+\sum_{j} I_{j, t}+\left(1+\theta_{1} B\right)\left(1+\theta_{2} B^{12}\right) \varepsilon_{t}
$$

Intervention variables (I)

Parameter estimate

Standard error

Constant
RP1999.Sep-1999.Dec
RP1999.Dec-2000.Feb
AO1951.Apr
LS1980.Dec
LS1982.Mar
TC1982.Jul
LS1984.Aug
AO1985.Dec
AO1986.Feb
LS1986.June
TC1986.Nov
LS1986.Dec
AO1987.May
LS1989.Feb
TC1989.Mar
AO1990.Feb
AO1990.Dec
AO1991.Dec
LS1992.Mar
LS1992.Sep
AO1999.Sep
TC2001.Sep
LS2001.Oct
$\varphi_{1}$
$\varphi_{2}$
$\theta_{1}$
$\theta_{2}$

$\begin{array}{r}0.0001 \\ 0.0886 \\ -0.1257 \\ 0.0282 \\ -0.0375 \\ -0.0333 \\ -0.0304 \\ -0.0316 \\ 0.0426 \\ -0.0259 \\ 0.0318 \\ 0.0314 \\ 0.0515 \\ 0.0326 \\ -0.0522 \\ 0.0364 \\ -0.0350 \\ 0.0320 \\ 0.0322 \\ 0.0427 \\ 0.0347 \\ 0.0407 \\ 0.2086 \\ -0.0705 \\ 0.2159 \\ 0.1305 \\ 0.3867 \\ 0.6104 \\ \hline\end{array}$

0.00292

0.00467

0.00547

0.00797

0.00866

0.00866

0.00836

0.00866

0.00776

0.00774

0.00879

0.00842

0.00879

0.00778

0.00951

0.00917

0.00784

0.00783

0.00795

0.00890

0.00870

0.00895

0.00980

0.01000

0.04152

0.04046

0.03828

0.03294 


\section{Figure 1}

Seasonal Factors for the Adjusted Monetary Base and Adjusted Reserves

Adjusted Monetary Base (monthly, Jan 1950-Dec 2003)

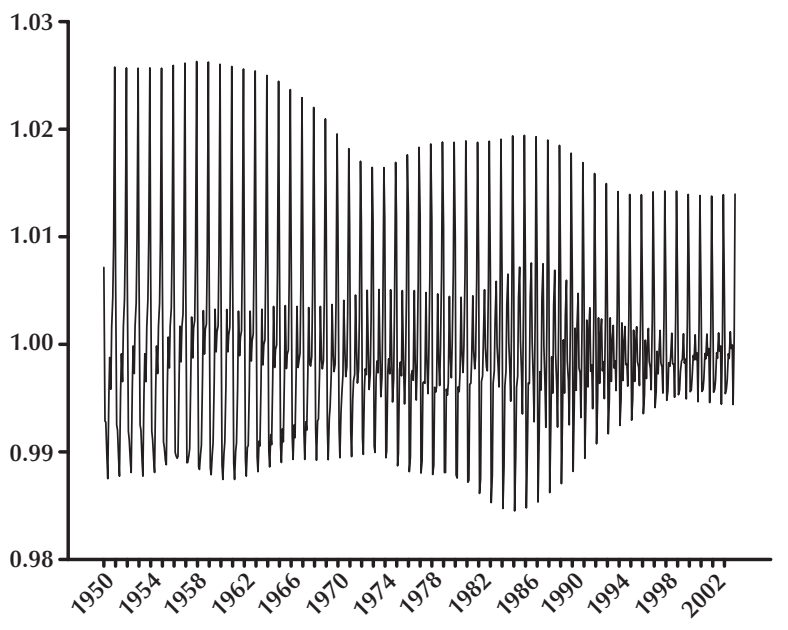

Adjusted Reserves (monthly, Jan 1950-Dec 2003)

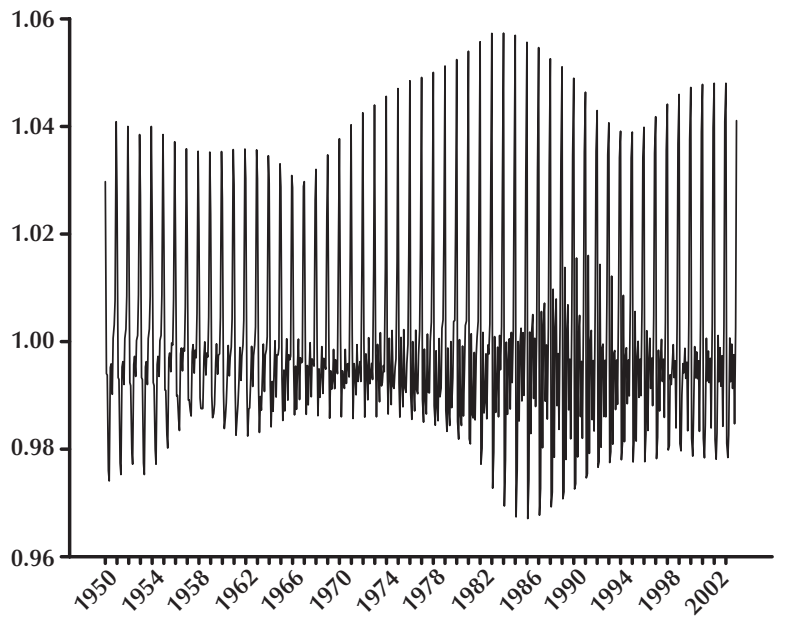

\section{EXTRAPOLATIONS OF RAM(1991) AFTER A BENCHMARK}

Observations on the adjusted monetary base and adjusted reserves beginning January 1994 include the variant of RAM(1991) developed in Anderson and Rasche (2001), which interprets a bank's implementation of a retail-deposit sweep program as economically equivalent to a reduction in the bank's statutory reserve requirements. ${ }^{28}$ The Anderson-Rasche variant of RAM(1991) must be estimated from panel data on individual banks because each bank has complete discretion regarding when (and whether) to implement a retail-deposit sweep program, as well as the intensity with which it sweeps transaction deposits. An important finding of Anderson and Rasche (2001) is that many banks, previously constrained by statutory reserve requirements, have been able to reduce their level of statutory required reserves below the amount of base money (vault cash plus deposits at Federal Reserve Banks) that they must hold for use in their normal day-to-day business. For these banks, the correct size of the RAM adjustment is smaller than the decrease in the bank's required reserves. Hence, updating RAM(1991) requires identifying sweeping banks and estimating the size of the effect of the sweep activity on each bank's holdings of base money. As a result, it is costly to update RAM(1991) frequently and, between benchmarks, published values must be constructed from aggregate figures.

The Anderson-Rasche (2001) analysis separates banks into three categories, based on whether or not they have a retail-deposit sweep program and whether or not, during any specific period $t$, they are constrained by statutory reserve requirements, that is, whether the partial derivative of the bank's base-money demand function with respect to the statutory reserve-requirement ratio is greater than zero. ${ }^{29}$ In that analysis, banks that are constrained by statutory reserve requirements are referred to as economically bound, or e-bound; banks not soconstrained are referred to as economically non-

\footnotetext{
${ }^{28}$ Retail-deposit sweep programs function as follows: A bank, subject to certain restrictions, moves customer funds from transaction deposits, subject to reserve-requirement ratios as high as 10 percent, into savings deposits, subject to a zero reserve-requirement ratio. Because customers generally are unaware of these reclassifications and likely share little, if any, of the bank's cost savings, the economic effect of such retaildeposit sweep programs closely resembles a change in the bank's statutory reserve requirements. On the latter point, see also Anderson (2002).

${ }^{29}$ For a bank to be included in our panel data set, it must have been constrained by reserve requirements during at least one reserve maintenance period between the beginning of 1991 and the end of 2001 . Hence, to be unconstrained during a specific period $t$, some circumstance that affects the bank must have changed. An appropriate measure of RAM ignores all such changes except changes in statutory reserve requirements. The categories mentioned in the text are implemented in our analysis by means of two time-series indicator variables, one marking the presence or absence of a retail-deposit sweep program and the other whether, in our judgment, the bank is constrained by statutory reserve requirements. For further discussion of the creation of these indicator variables, see Anderson and Rasche (2001).
} 


\section{Table 3}

\section{The Five Segments of the Reserve Adjustment Magnitude}

\begin{tabular}{|c|c|c|}
\hline Date span & $\begin{array}{l}\text { Date of base period } \\
\text { statutory reserve } \\
\text { requirements }\end{array}$ & Description \\
\hline \multicolumn{3}{|l|}{ RAM(1922): } \\
\hline August 1917-August 1935 & July 1922 & $\begin{array}{l}\text { On July } 1,1922, \text { St. Louis was classified as a reserve city, } \\
\text { rather than a central reserve city. This reduced the } \\
\text { reserve-requirement ratio on net demand deposits at } \\
\text { larger St. Louis banks to } 10 \text { percent from } 13 \text { percent. }\end{array}$ \\
\hline \multicolumn{3}{|l|}{ RAM(1935): } \\
\hline $\begin{array}{l}\text { September 1935- } \\
\text { December } 1972\end{array}$ & September 1935 & $\begin{array}{l}\text { In August 1935, the Banking Act of } 1935 \text { imposed on U.S. } \\
\text { government demand deposits the same reserve require- } \\
\text { ment as applied to private demand deposits. The act also } \\
\text { changed the definition of net demand deposits subject } \\
\text { to reserve requirements so as to allow deductions of } \\
\text { certain items against all demand deposits rather than just } \\
\text { deposits due to banks. During August 1935, the changes } \\
\text { increased required reserves by approximately } \$ 35 \text { million, } \\
\text { relative to their amount using the July } 1922 \text { requirements. }\end{array}$ \\
\hline \multicolumn{3}{|l|}{$\operatorname{RAM}(1972):$} \\
\hline December 1972-January 1975 & December 1972 & $\begin{array}{l}\text { Net demand deposits became subject to a graduated } \\
\text { (tiered) system of requirements. Previous categories of } \\
\text { central reserve city, reserve city, and country bank were } \\
\text { eliminated. }\end{array}$ \\
\hline \multicolumn{3}{|l|}{ RAM(1975): } \\
\hline January 1975-October 1980 & January 1975 & $\begin{array}{l}\text { Time deposits became subject to a graduated system of } \\
\text { requirements that also depended on deposit maturity. }\end{array}$ \\
\hline \multicolumn{3}{|l|}{ RAM(1991): } \\
\hline November 1980 to date & January 1991 & $\begin{array}{l}\text { Effective November } 1980 \text {, the Monetary Control Act sub- } \\
\text { stantially changed the reserve requirement system. In } \\
\text { December 1990, time and savings deposits became subject } \\
\text { to a zero percent reserve requirement. }\end{array}$ \\
\hline
\end{tabular}

bound, or e-nonbound. Being e-bound or e-nonbound is not an absorbing state, that is, individual banks can and do move between categories within the sample.

1. For banks that are e-nonbound during period $t$ and do not have a retail-deposit sweep program, $R A M(1991)_{t}=0$. (Note that, prior to implementing their sweep programs, many of these banks were e-bound and fell within category 3 below.)

2 . For a bank that, during period $t$, does have a retail-deposit sweep program and becomes economically nonbound as a result of implementing that program, $\operatorname{RAM}(1991)_{t}=$ $R R_{t_{0}, 9 J a n 1991}-M B_{t_{0}}^{*}$, where $t_{0}$ is the implementation date (reserve maintenance period) of the sweep program; $R R_{t_{0}, 9 \mathrm{Jan} 1991}$ is an estimate of the bank's required reserves during period $t_{0}$ if the reserve-requirement regime of the reserve maintenance period ending January 9 , 1991, had been in effect (calculated using the sum of the bank's reported net transaction deposits plus our estimate of the amount of net transaction deposits reclassified as saving deposits via the retail-deposit sweep program); and $M B_{t_{0}}^{*}$ is an estimate of the amount of base money that would have been held by the bank if it were at the margin between e-bound and e-nonbound. Note that the RAM adjustment for these banks is a constant amount after date $t_{0}$ unless there is a material change in the character of the bank such as discontinuing the sweep program or participating in a merger. 
3. For an e-bound bank, with or without a retail-deposit sweep program, $R A M(1991)_{t}=$ $R R_{t, 9 J a n 1991}-R R_{t}$. In our panel, not every bank that implements a retail-deposit sweep program becomes e-nonbound. Some banks, for whatever reason, do not sweep enough deposits to fully remove the constraining effects of statutory reserve requirements on their balance sheets. As in category 2, the counterfactual $R R_{t, 9 \text { Jan } 1991}$ is calculated using the sum of reported net transaction deposits plus our estimate of the amount of net transaction deposits reclassified as saving deposits by means of the retail-deposit sweep program.

To extend RAM(1991) forward beyond the benchmark reserve maintenance period, $b$ (here, the period ending September 30, 2002), note that, as of the benchmark period, the RAM values for banks in the first two categories are constants, either zero or positive numbers. Hence, we carry forward to future periods the aggregate of these constants, denoted $A_{0}$. Then, because all banks in the third category have net transaction deposits greater than the low-reserve tranche, aggregate RAM as of the benchmark period may be written as the sum of a constant, plus 12 percent of the aggregate net transaction deposits at e-bound banks (those banks in category 3), minus the aggregate required reserves of e-bound banks:

$$
\begin{aligned}
& R A M(1991)_{b} \\
& =A_{0, b}+0.12 *\left(D_{b}-N * \text { Tranche }\right) \\
& +0.03 * N *(\text { Tranche }- \text { Exemption })-R R_{b} \\
& =A_{1, b}+0.12 * D_{b}-R R_{b},
\end{aligned}
$$

where $N$ denotes the number of e-bound banks, $D_{30 \text { Sep2002 }}$ denotes their aggregate net transaction deposits (including deposits involved in retaildeposit sweep programs), $R R_{b}$ denotes their total required reserves, and Tranche and Exemption are the low-reserve tranche and reserve-exemption amount, respectively, during the base period (the reserve maintenance period ending January 9 , 1991). ${ }^{30}$ Then, in the absence of figures on individual banks, we extend $R A M(1991)_{t}$ forward, for periods $t>26$ Dec2001, with the equation

\footnotetext{
30 The low-reserve tranche and reserve-exemption amounts are subject to statutory reserve-requirement ratios of 3 percent and zero, respectively. For the reserve maintenance period ending January 9, 1991, the low-reserve tranche was $\$ 41.1$ million and the reserve-exemption amount was $\$ 3.4$ million. For the benchmark reserve maintenance period ending September 30,2002 , the amounts were $\$ 42.8$ million and $\$ 5.5$ million.
}

$$
R A M(1991)_{t}=A_{1, b}+0.12 * \delta_{D} * A g g D_{t}-\delta_{R} * A g g R R_{t},
$$

where $A g g D_{t}$ is the transaction-deposit component of M1 (demand deposits, not seasonally adjusted, plus other checkable deposits, not seasonally adjusted); $A g g R R_{t}$ is aggregate required reserves at all banks;

$$
\delta_{D}=\frac{D_{b}}{A g g D_{b}}
$$

where $D_{b}$ is the transaction deposits of e-bound banks during the benchmark reserve maintenance period; and

$$
\delta_{R}=\frac{R R_{b}}{A g g R R_{b}}
$$

where $R R_{b}$ is the required reserves of e-bound banks during the benchmark period. During the benchmark reserve maintenance period in this analysis, ending September 30, 2002, $\delta_{D}=0.192$ and $\delta_{R}=0.095$.

\section{THE PREVIOUS AND REVISED ADJUSTED MONETARY BASE}

Differences between our revised series and the previously published figures are shown for the monetary base and adjusted reserves, respectively, in Figures 2 and 3. For clarity, the time series are separated into three segments-1936-58, 1959-79, and 1980-2002. Note that the vertical scales differ. ${ }^{31}$ In each figure, the charts in panel A compare the levels of the series and the charts in panel B compare the compound annual growth rates.

Overall, the revised and current levels for the adjusted monetary base and adjusted reserves (panels A) are relatively close until the acceleration of retail-deposit sweep programs during April 1995. During 1936-68, the major issue is correction of the timing error in RAM(1935), a correction that primarily affects pairs of adjacent months. For reserves, the revision due to this change sometimes is as large as 10 percent of the level. Spikes in the difference between the levels of the revised and current series are apparent in late 1972 (positive) and late 1975 (negative), due to our corrections to RAM(1972) and RAM(1975). With respect to growth rates (panels B), the corrections to RAM(1935) cause large revi-

\footnotetext{
31 Adjusted monetary base figures are not shown prior to 1936 because these figures did not change. Also, no "previous" series is shown for adjusted reserves because figures were not published for dates prior to 1947 .
} 


\section{Figure 2}

\section{Adjusted Monetary Base, Revised and Previous Series}

A.

Levels, Part 1 (billions of dollars, not seasonally adjusted, monthly, 1936-58)

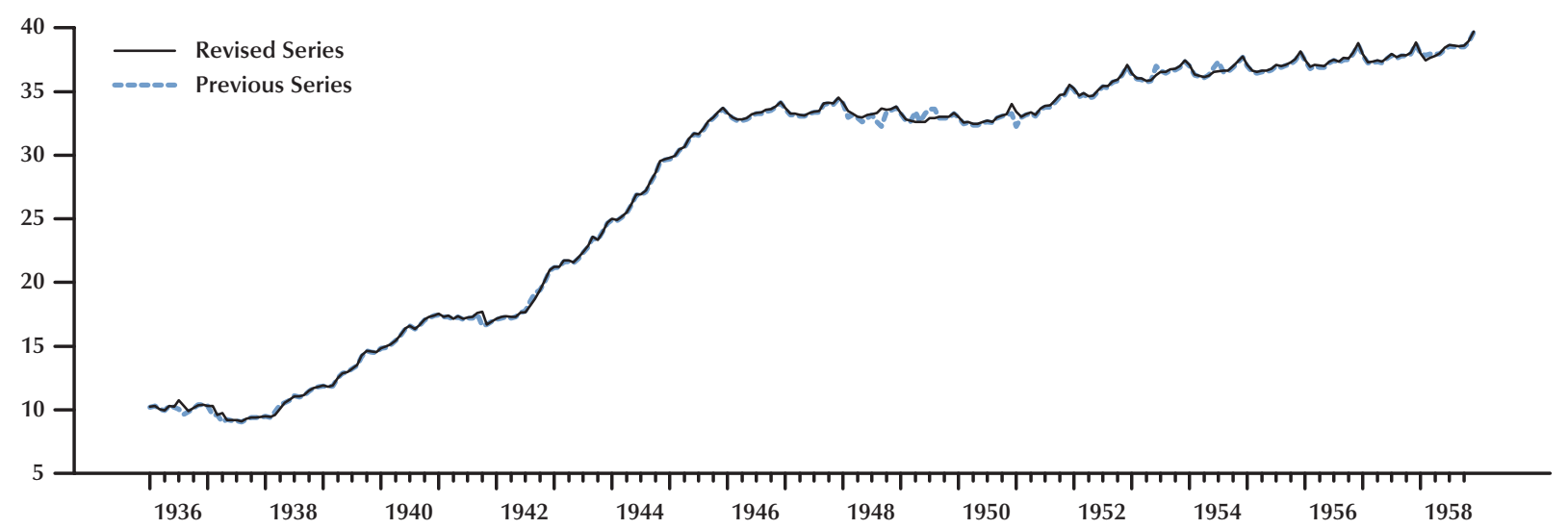

Revised Series Minus Previous Series, Part 1 (billions of dollars, not seasonally adjusted)

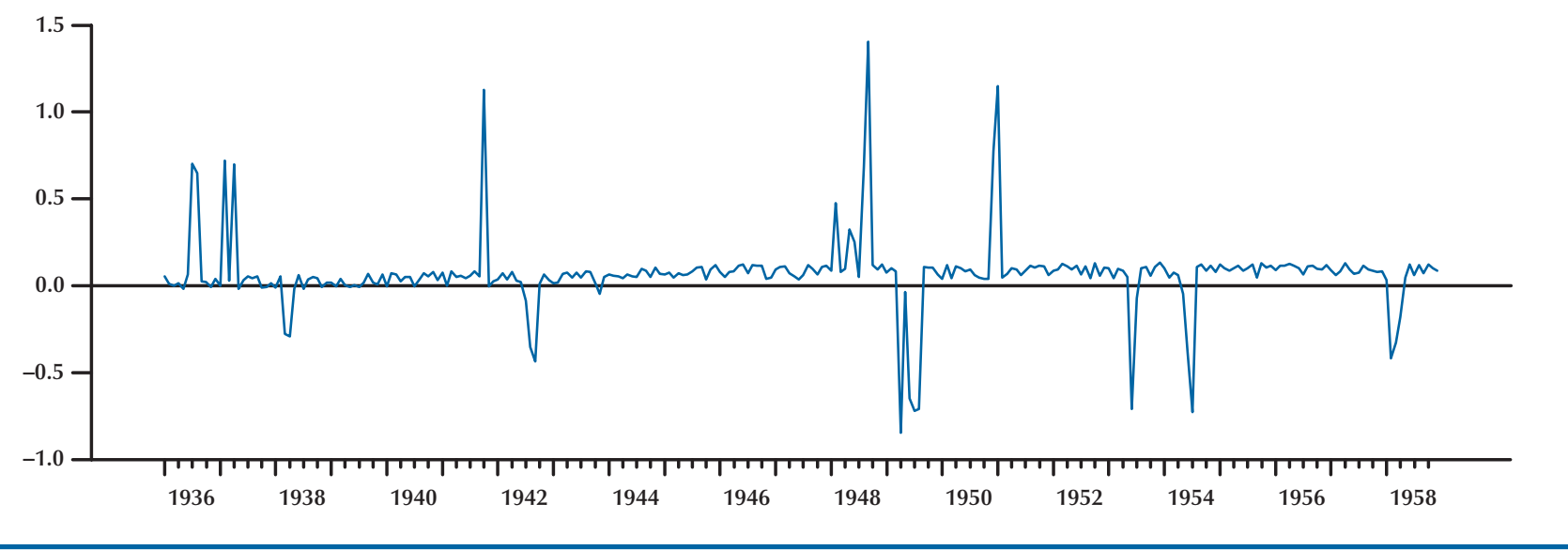

sions to some monthly growth rates during 1936-37, late 1941, and late 1961. (Once again, note the differences in vertical scale.)

\section{SUMMARY}

This analysis has summarized the results of an extensive reconstruction of the Federal Reserve Bank of St. Louis adjusted monetary base and adjusted reserves. Minor revisions have been made to the monetary (source) base such that it is now measured for all periods, as closely as is feasible, as an average of daily figures. More important corrections have been made to three segments of the RAM adjustment to correct timing and normalization errors. A fourth segment, beginning in 1980, has been updated with new figures beginning in 1991. Seasonal adjustment factors also have been updated. 


\section{Figure 2 cont'd}

\section{Adjusted Monetary Base, Revised and Previous Series}

A.

Levels, Part 2 (billions of dollars, not seasonally adjusted, monthly, 1959-79)

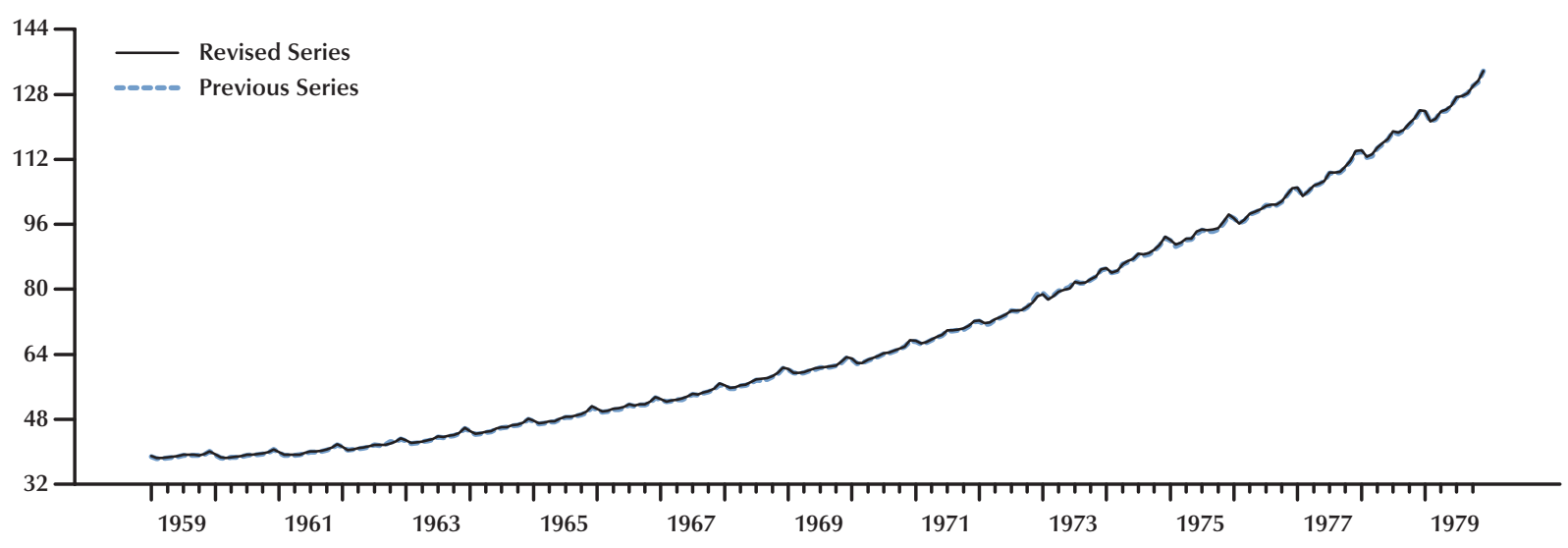

Revised Series Minus Previous Series, Part 2 (billions of dollars, not seasonally adjusted)

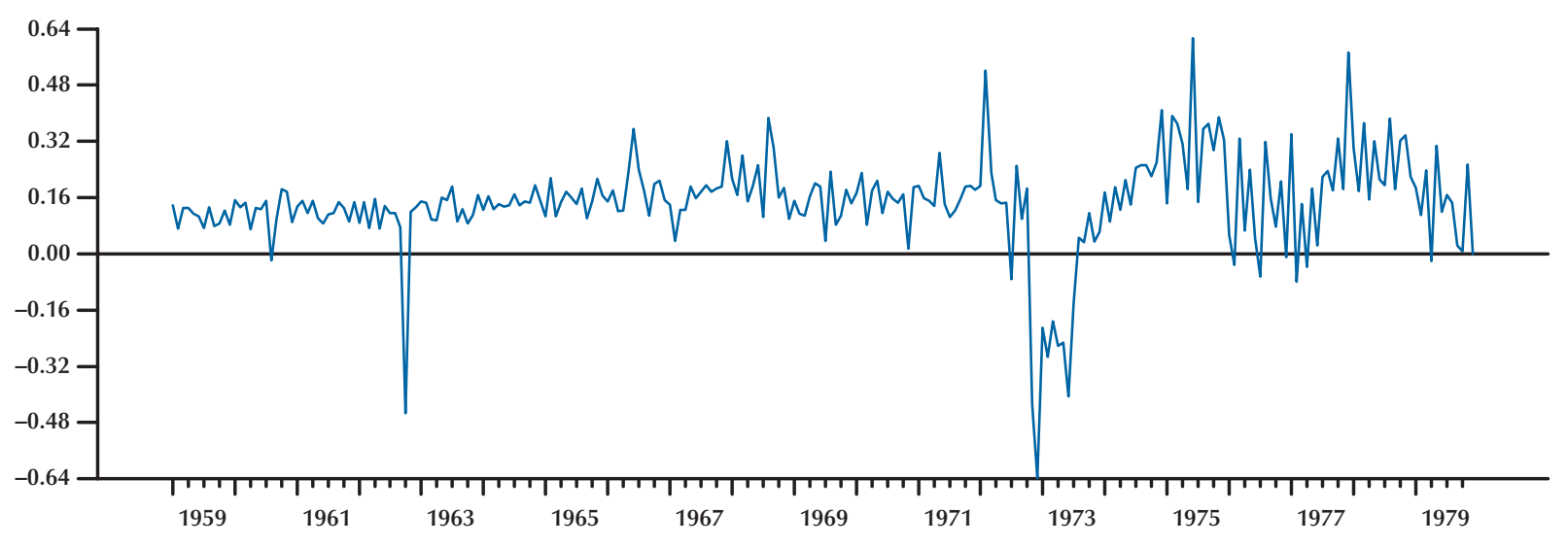




\section{Figure 2 cont'd}

\section{Adjusted Monetary Base, Revised and Previous Series}

A.

Levels, Part 3 (billions of dollars, not seasonally adjusted, monthly, 1980-2002)

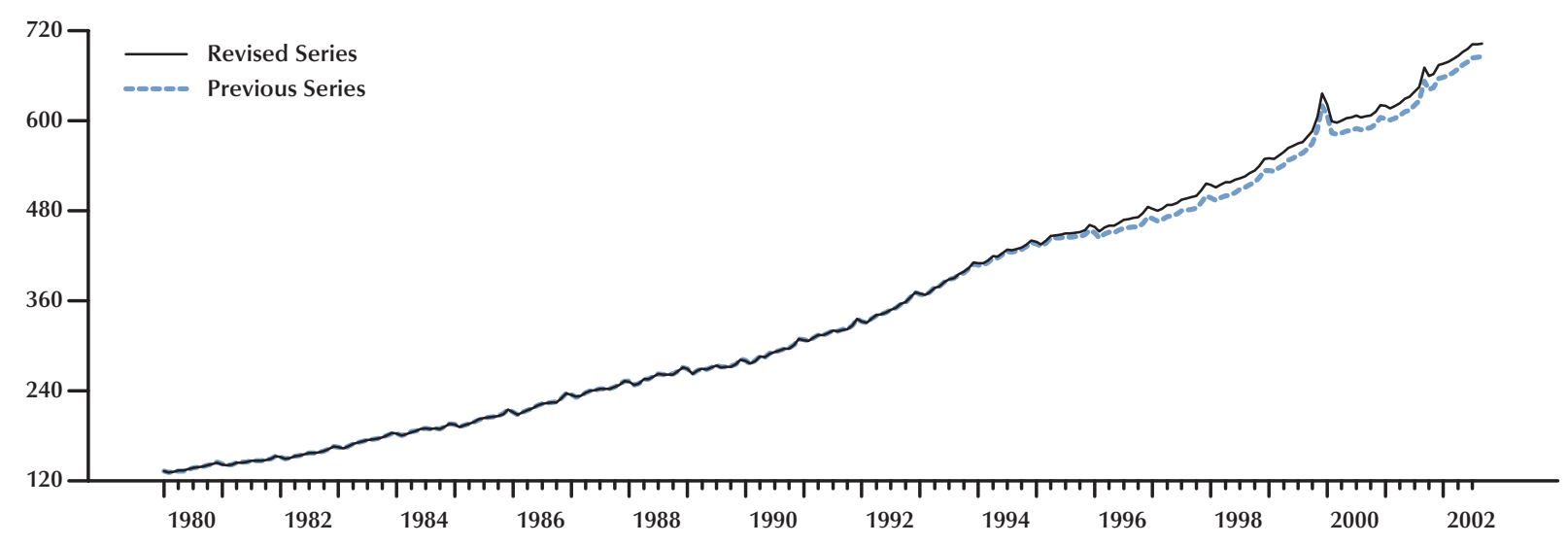

Revised Series Minus Previous Series, Part 3 (billions of dollars, not seasonally adjusted)

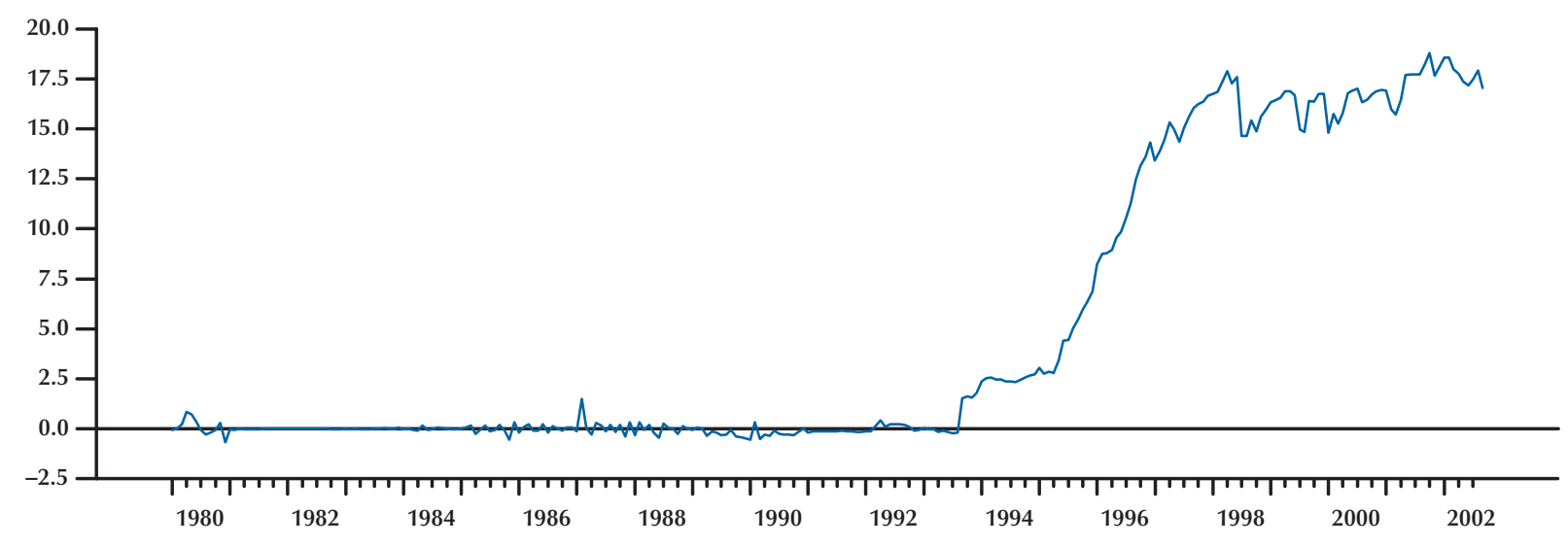




\section{Figure 2 cont'd}

\section{Adjusted Monetary Base, Revised and Previous Series}

B.

Growth Rate, Part 1 (monthly, compound annual rate, 1936-58)

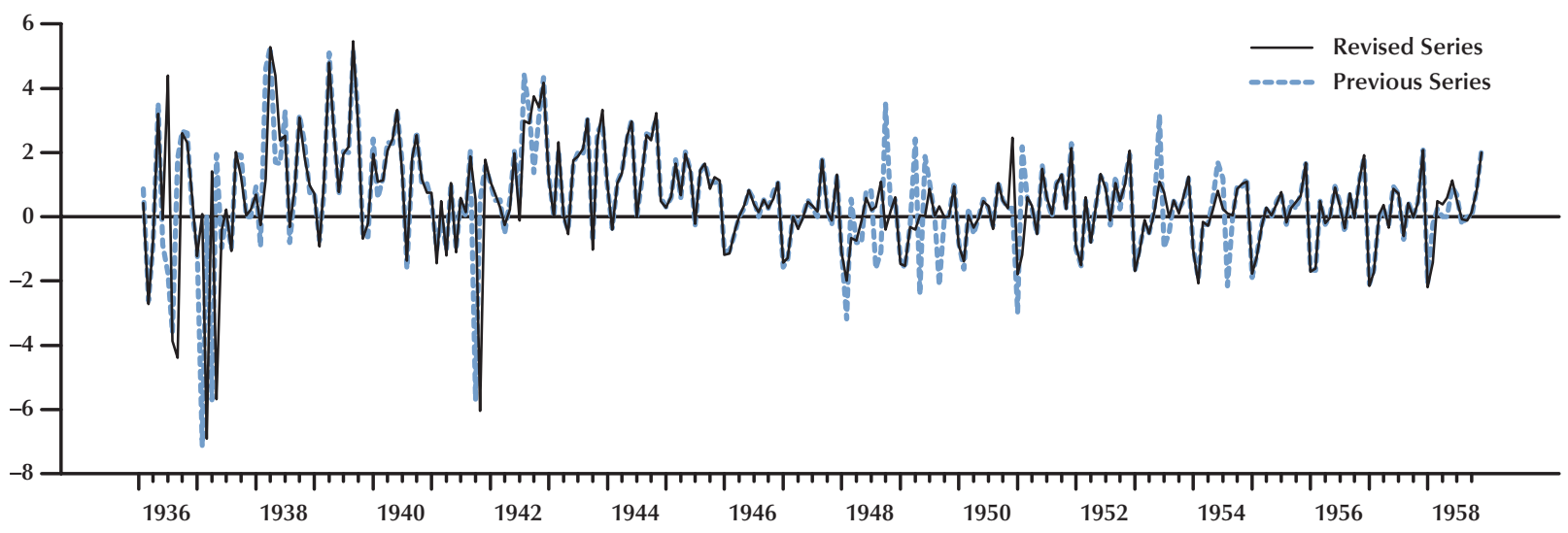

Revised Series Minus Previous Series, Part 1 (monthly, compound annual rate)

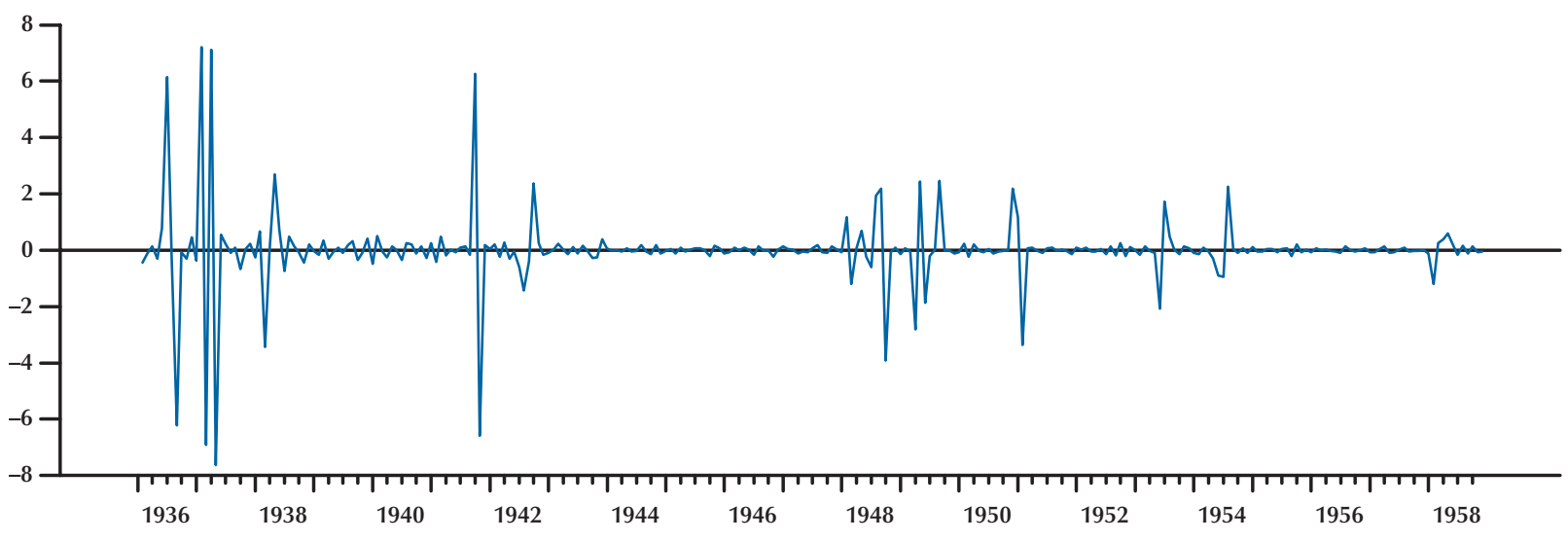




\section{Figure 2 cont'd}

\section{Adjusted Monetary Base, Revised and Previous Series}

B.

Growth Rate, Part 2 (monthly, compound annual rate, 1959-79)

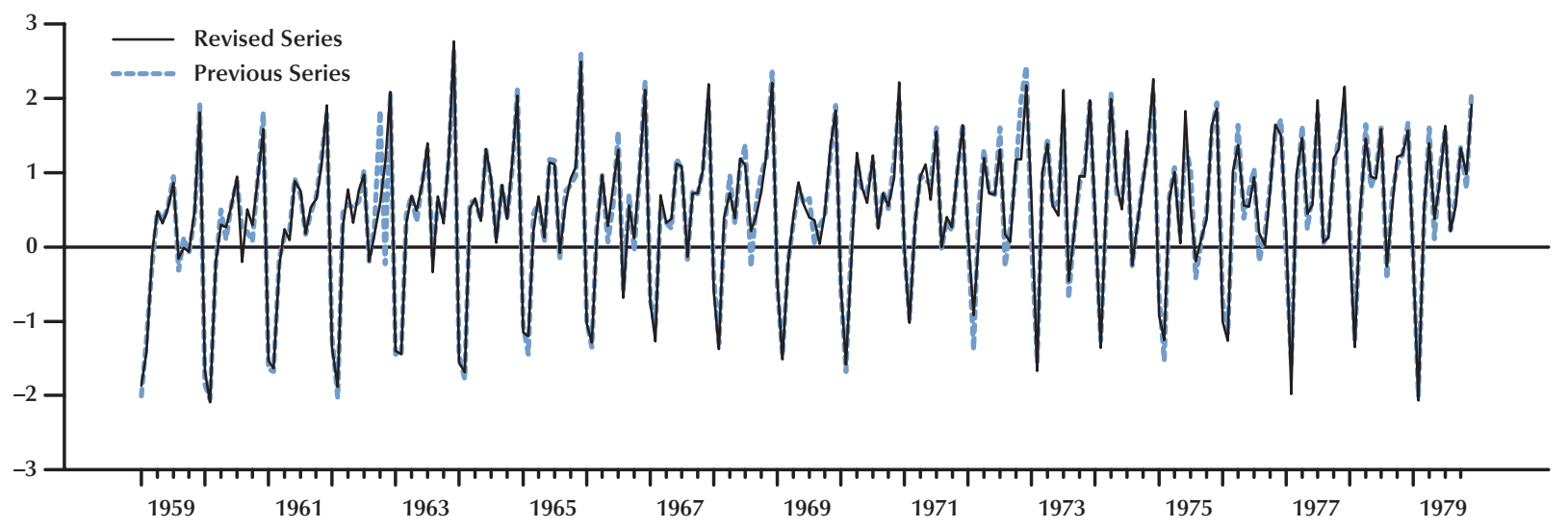

Revised Series Minus Previous Series, Part 2 (monthly, compound annual rate)

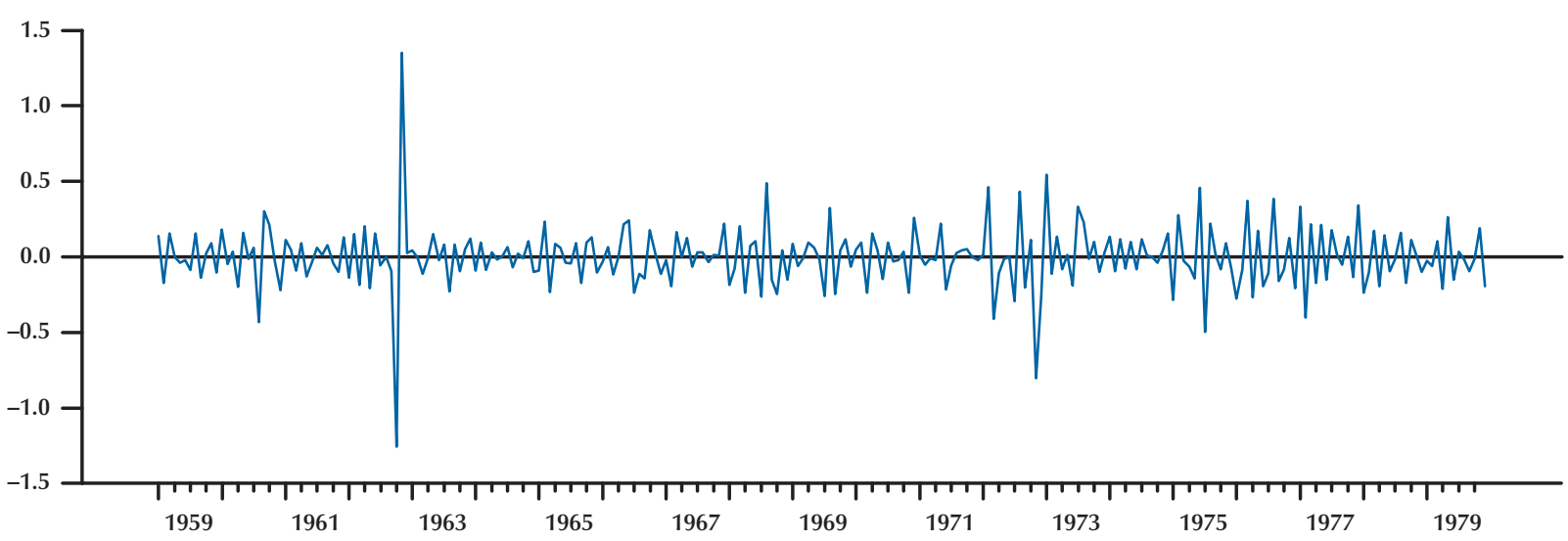




\section{Figure 2 cont'd}

Adjusted Monetary Base, Revised and Previous Series

B.

Growth Rate, Part 3 (monthly, compound annual rate, 1980-2002)

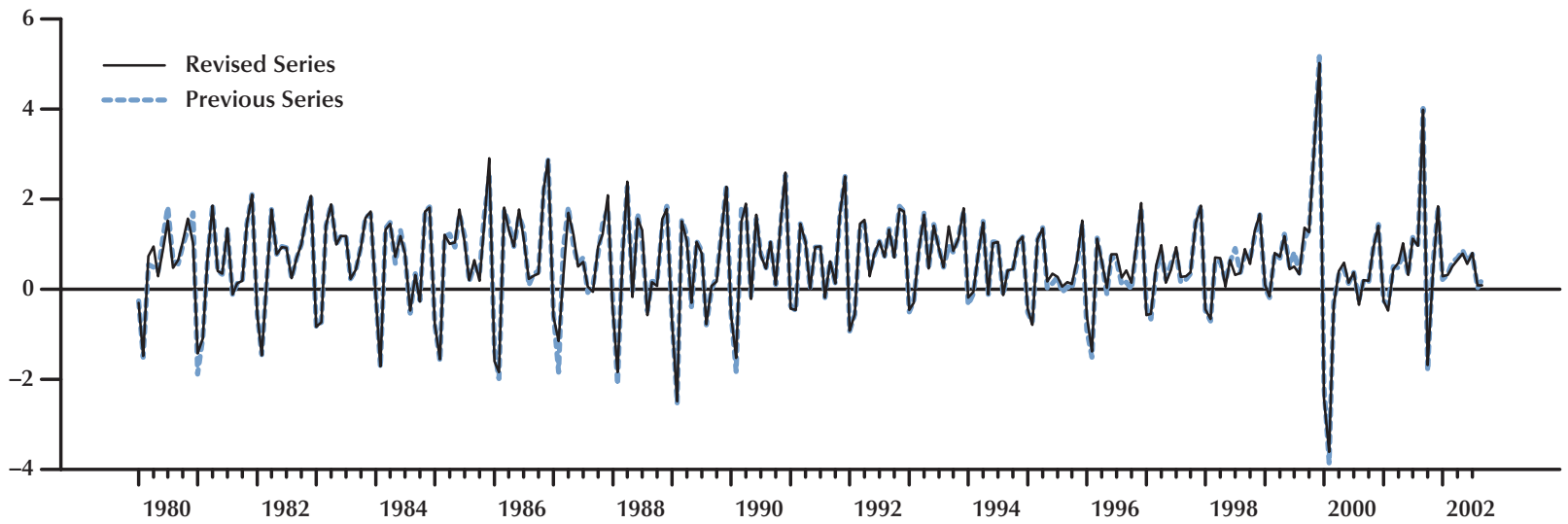

Revised Series Minus Previous Series, Part 3 (monthly, compound annual rate)

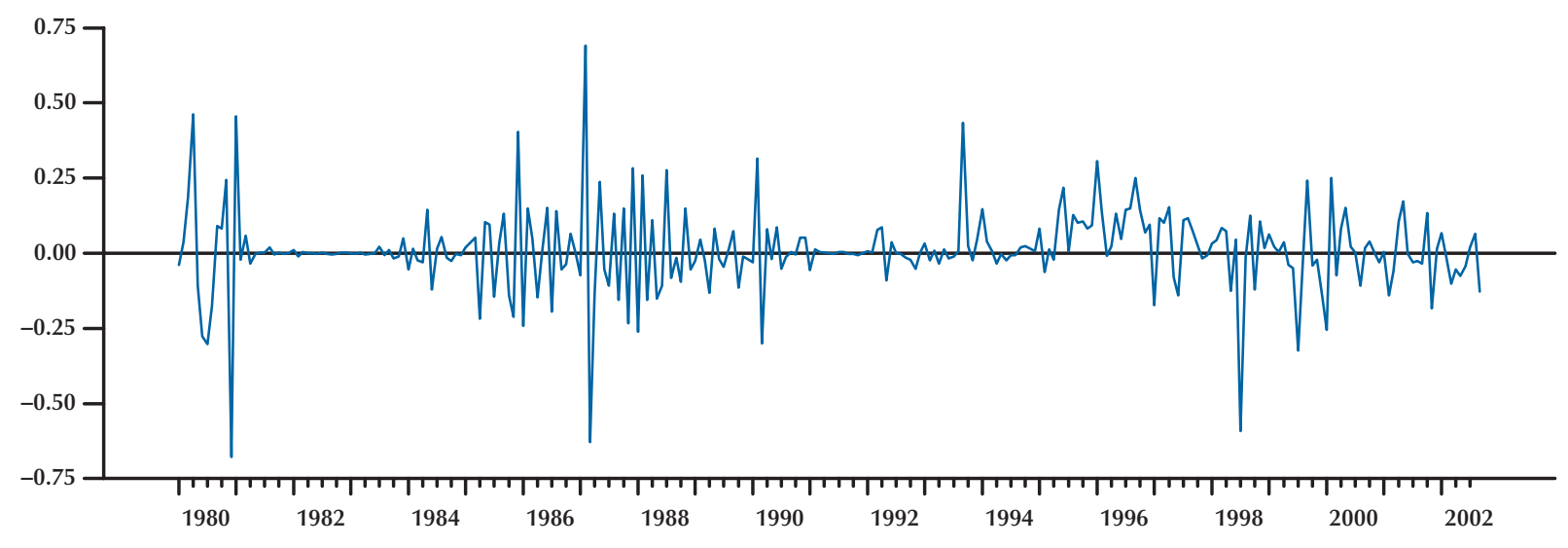




\section{Figure 3}

\section{Adjusted Reserves, Revised and Previous Series}

A.

Levels, Part 1 (billions of dollars, not seasonally adjusted, monthly, 1936-58)

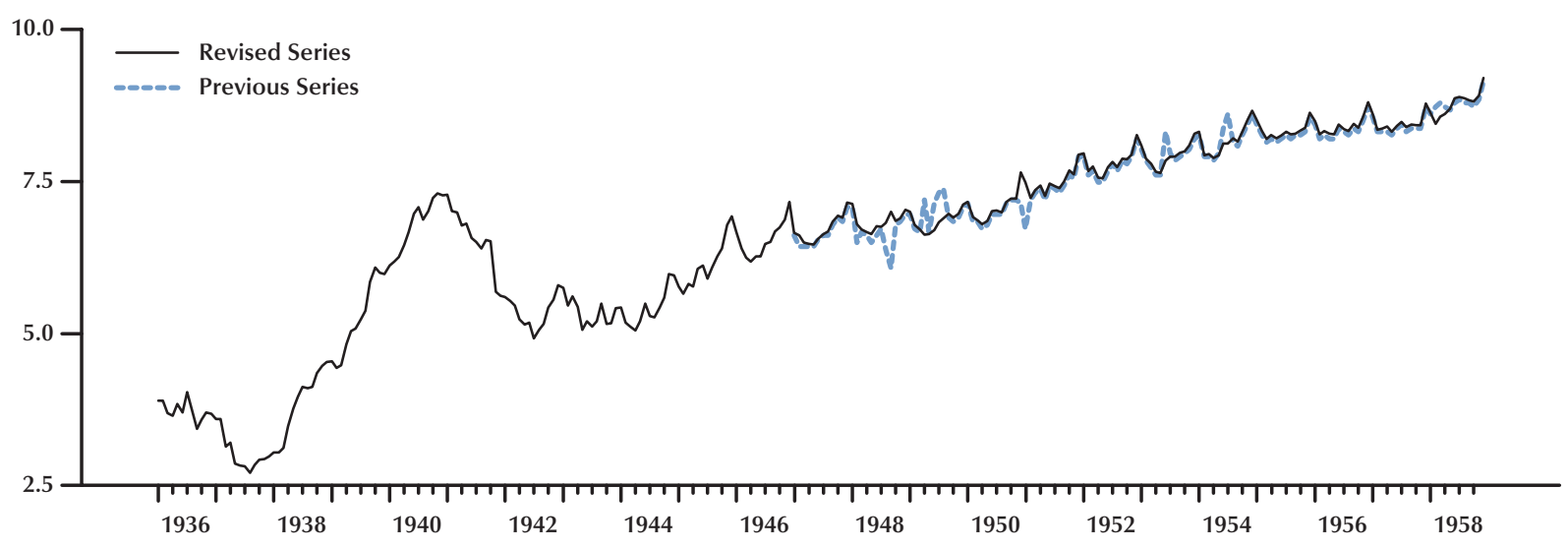

Revised Series Minus Previous Series, Part 1 (billions of dollars, not seasonally adjusted)

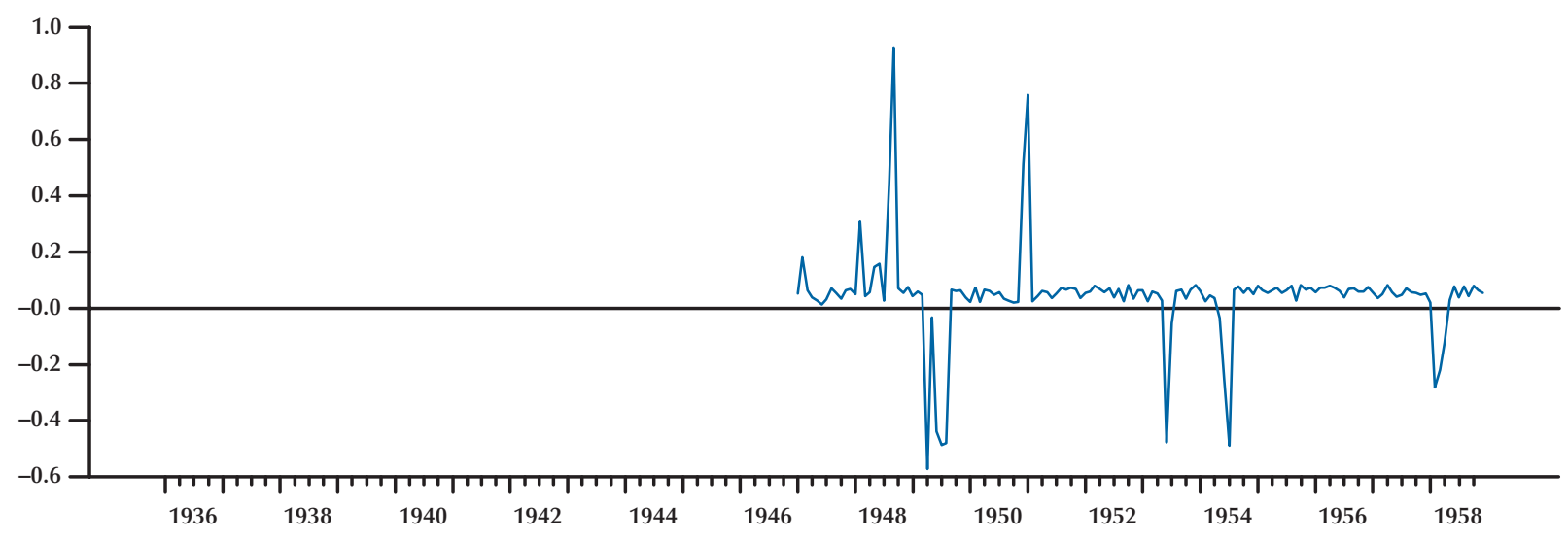




\section{Figure 3 cont'd}

\section{Adjusted Reserves, Revised and Previous Series}

A.

Levels, Part 2 (billions of dollars, not seasonally adjusted, monthly, 1959-79)

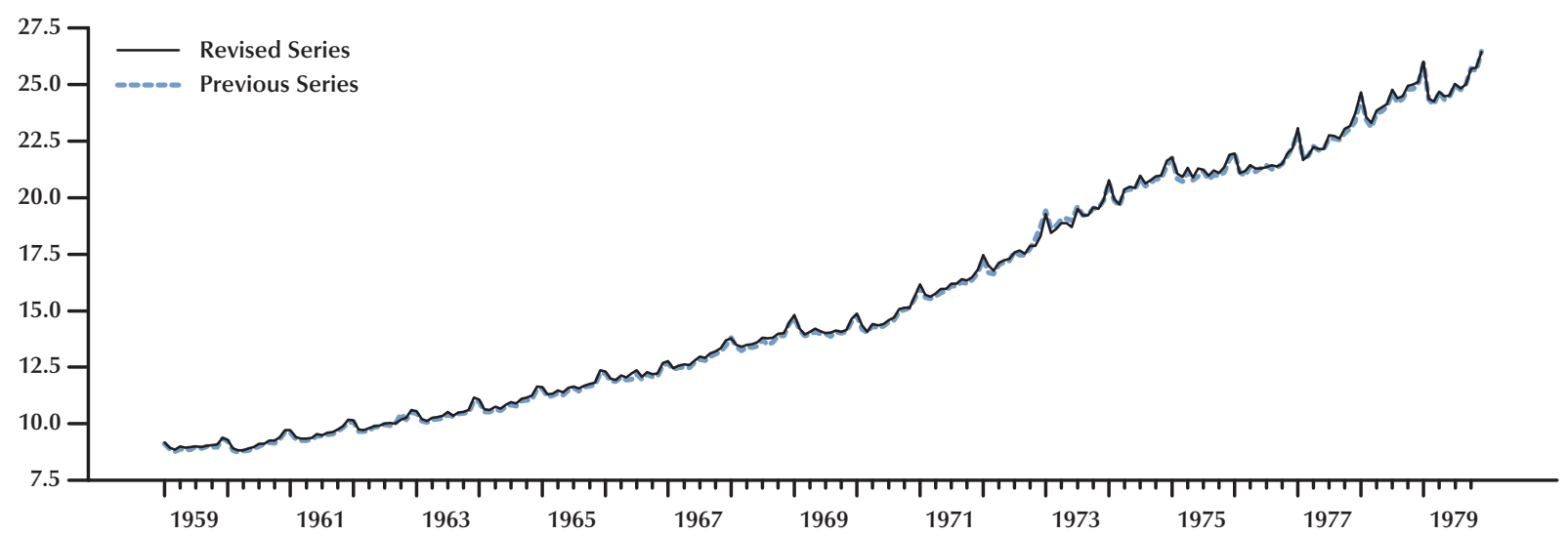

Revised Series Minus Previous Series, Part 2 (billions of dollars, not seasonally adjusted)

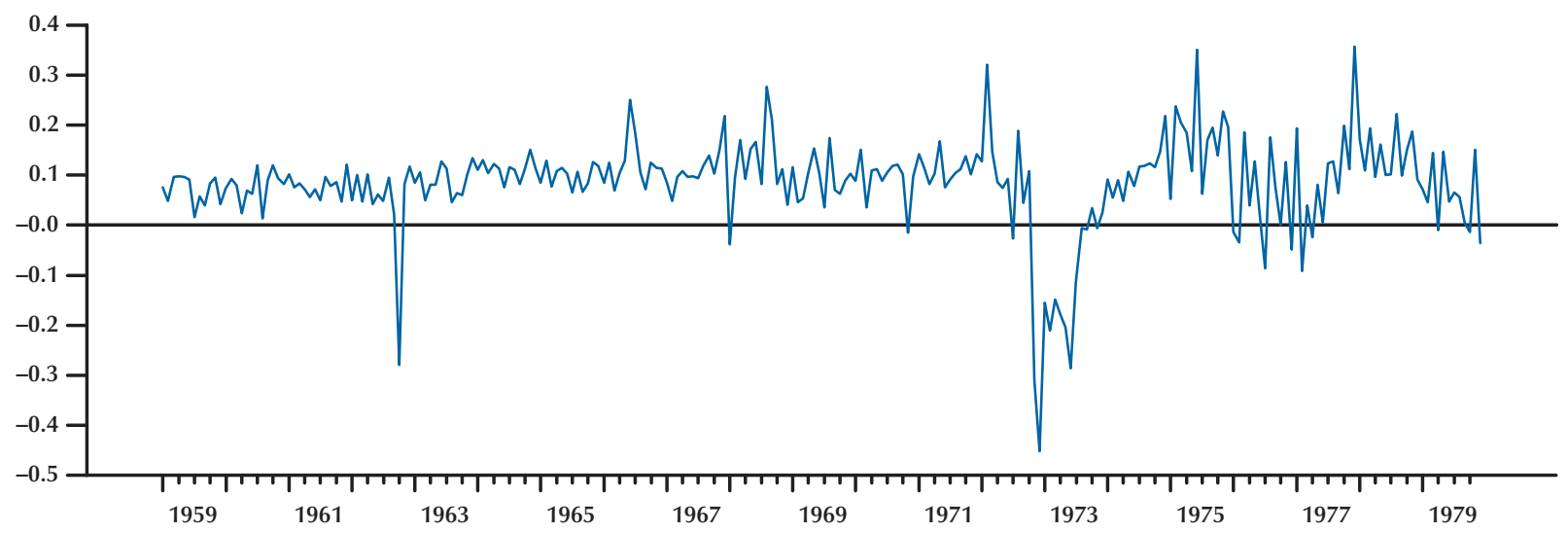




\section{Figure 3 cont'd}

\section{Adjusted Reserves, Revised and Previous Series}

A.

Levels, Part 3 (billions of dollars, not seasonally adjusted, monthly, 1980-2002)

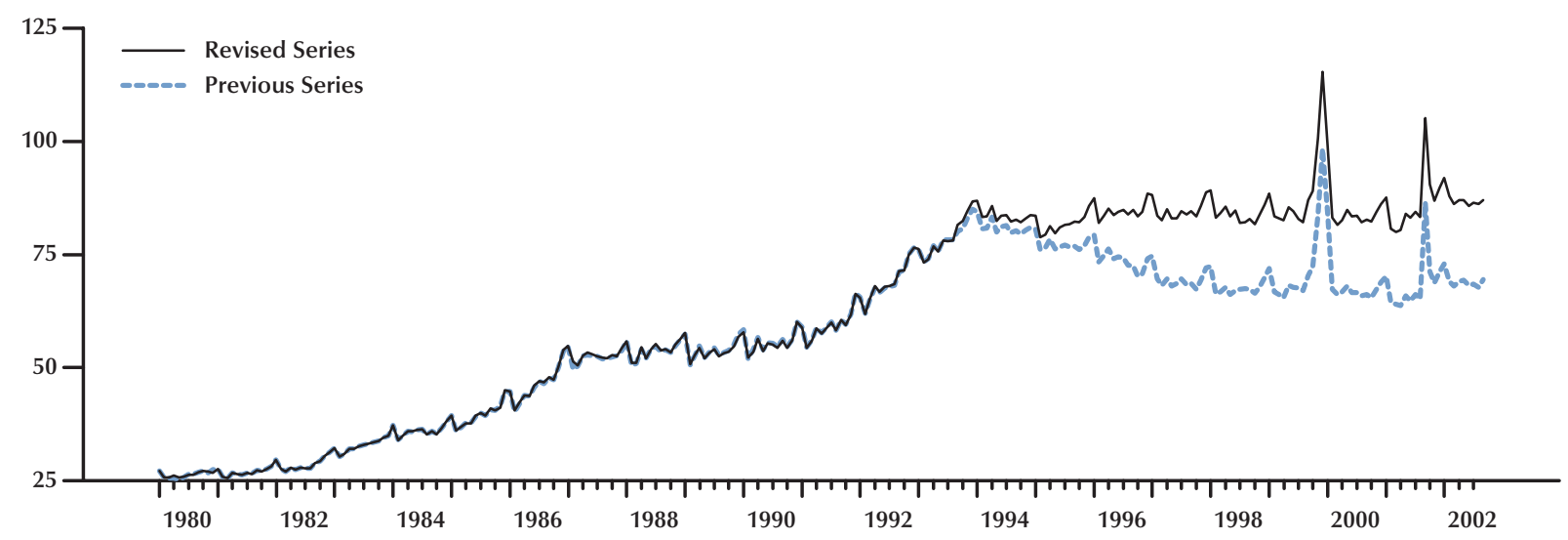

Revised Series Minus Previous Series, Part 3 (billions of dollars, not seasonally adjusted)

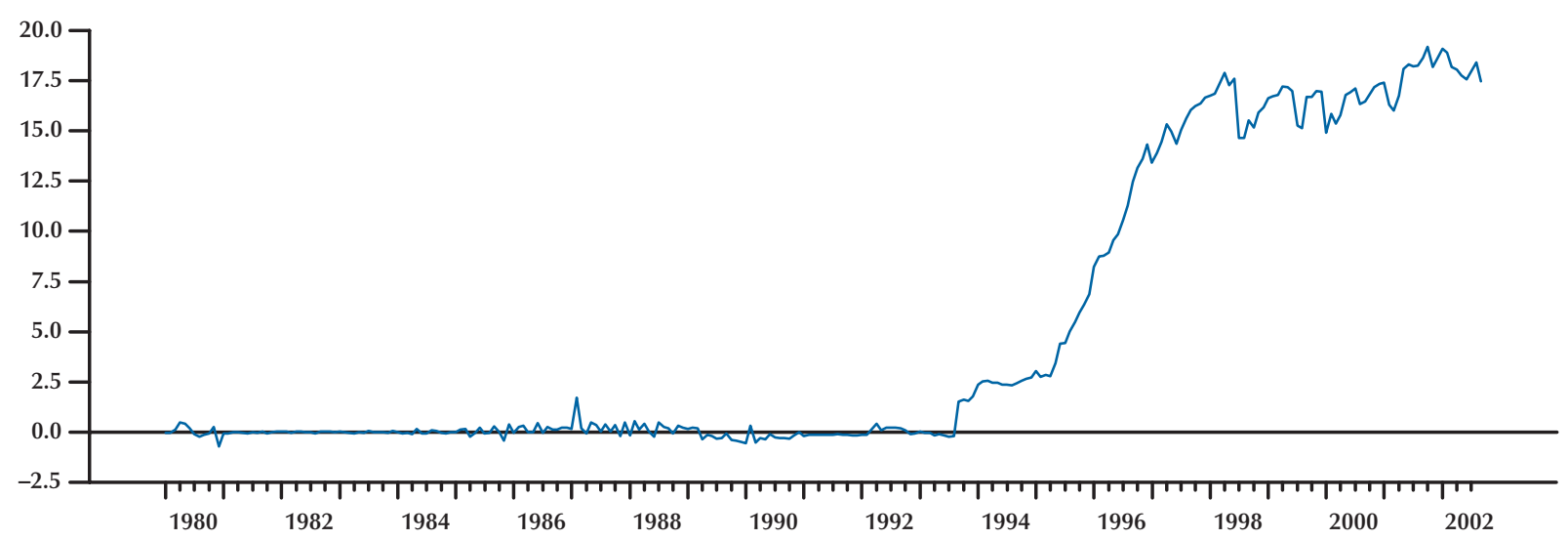




\section{Figure 3 cont'd}

Adjusted Reserves, Revised and Previous Series

B.

Growth Rate, Part 1 (monthly, compound annual rate, 1936-58)

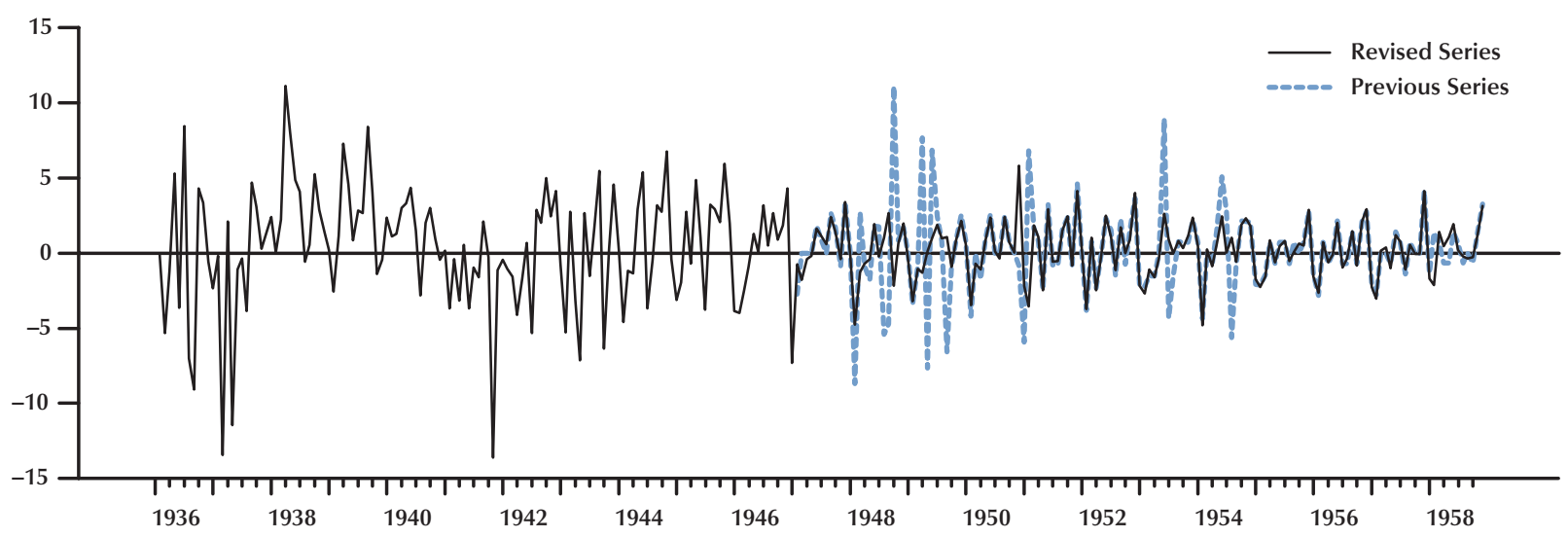

Revised Series Minus Previous Series, Part 1 (monthly, compound annual rate)

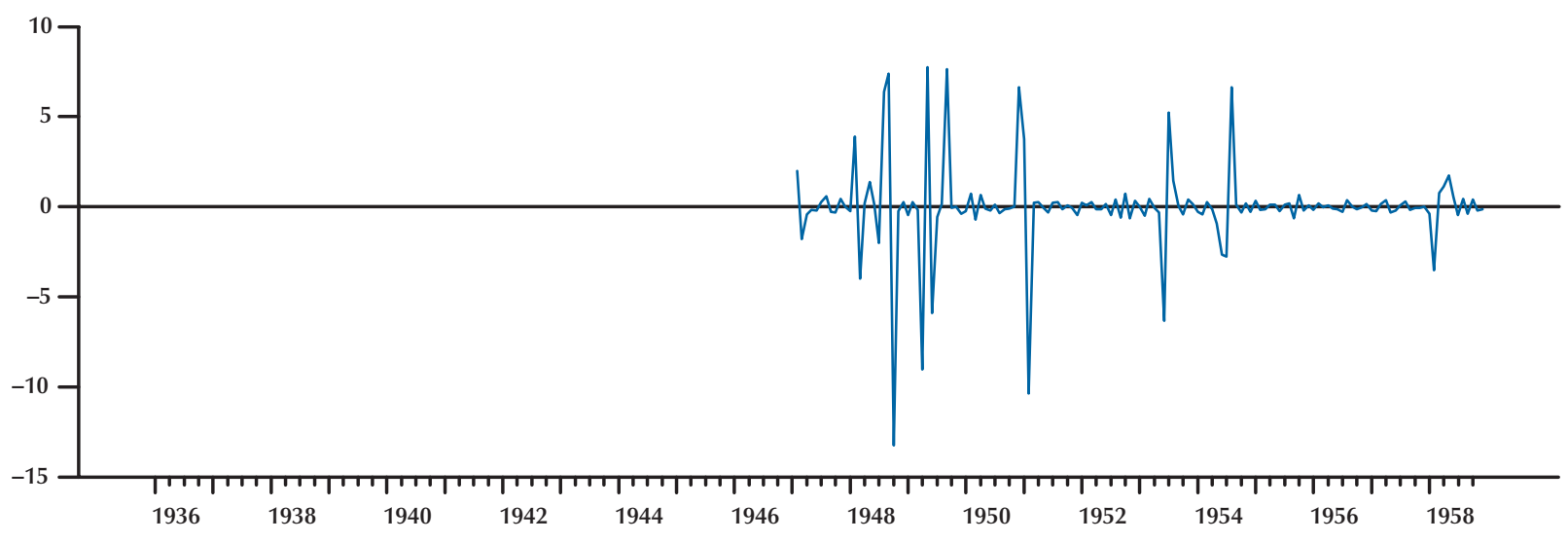




\section{Figure 3 cont'd}

\section{Adjusted Reserves, Revised and Previous Series}

B.

Growth Rate, Part 2 (monthly, compound annual rate, 1959-79)

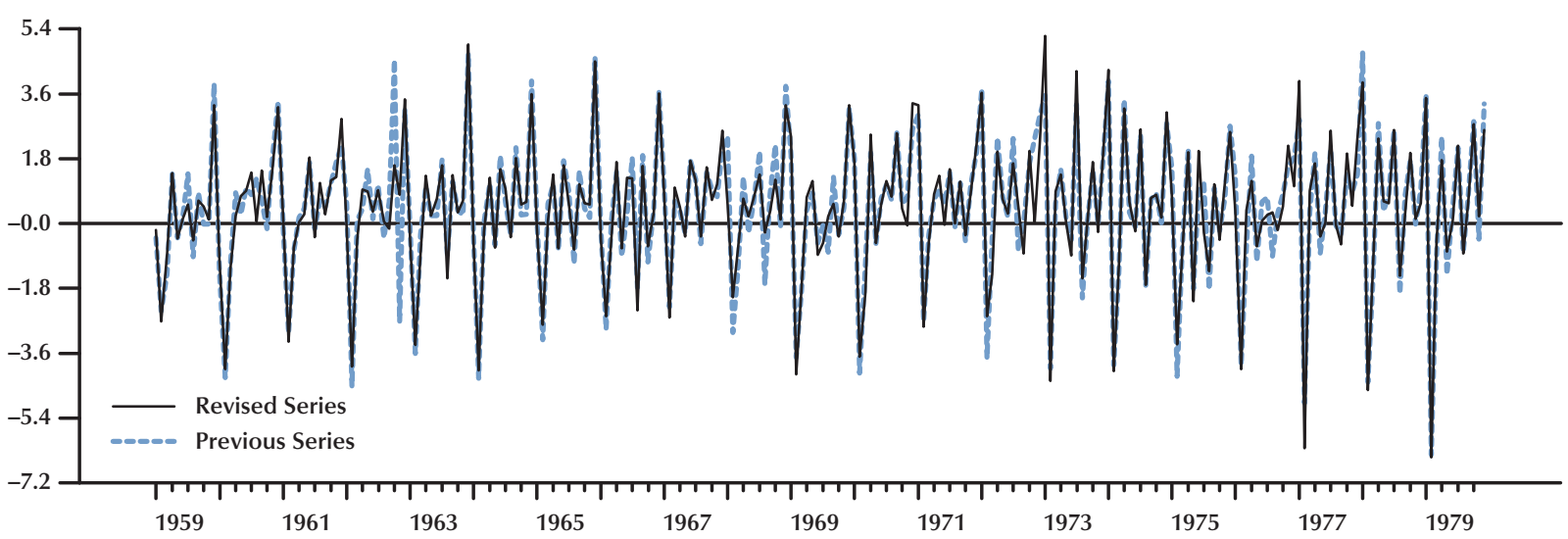

Revised Series Minus Previous Series, Part 2 (monthly, compound annual rate)

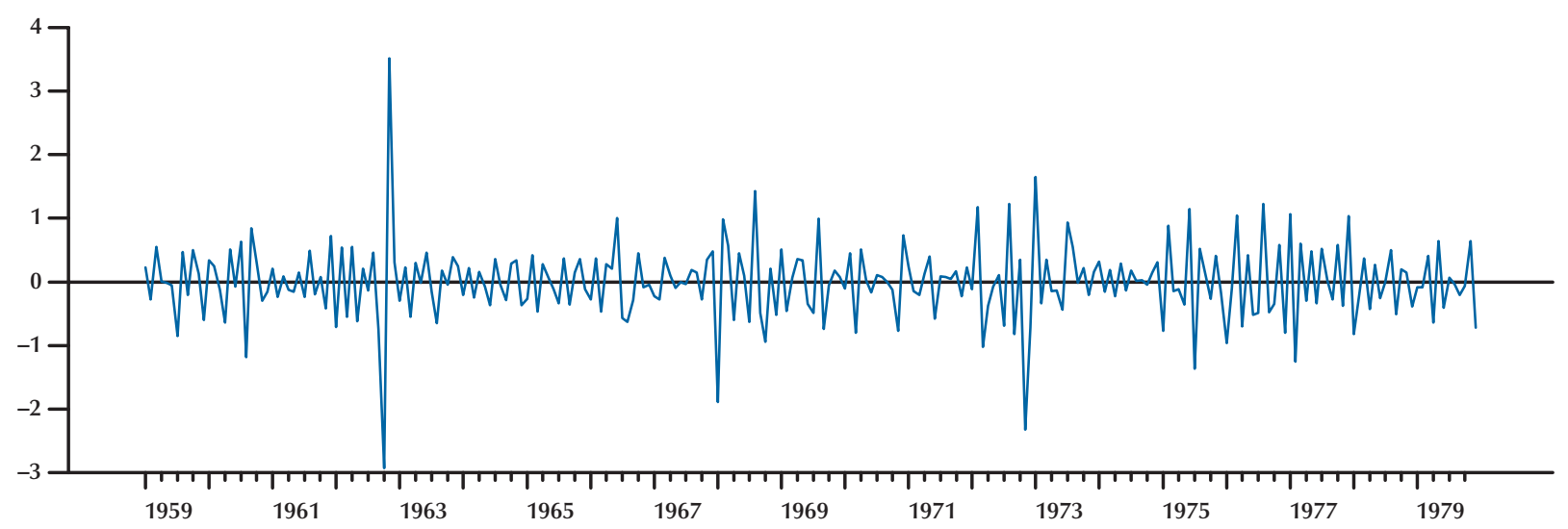




\section{Figure 3 cont'd}

\section{Adjusted Reserves, Revised and Previous Series}

B.

Growth Rate, Part 3 (monthly, compound annual rate, 1980-2002)

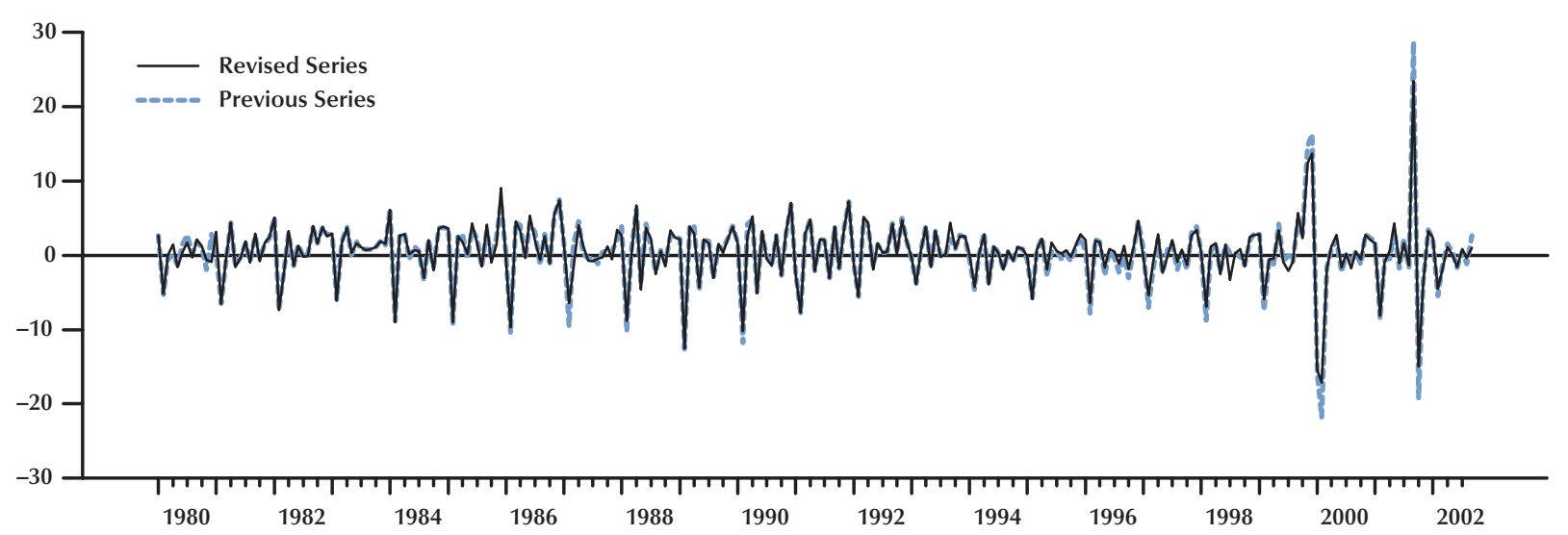

Revised Series Minus Previous Series, Part 3 (monthly, compound annual rate)

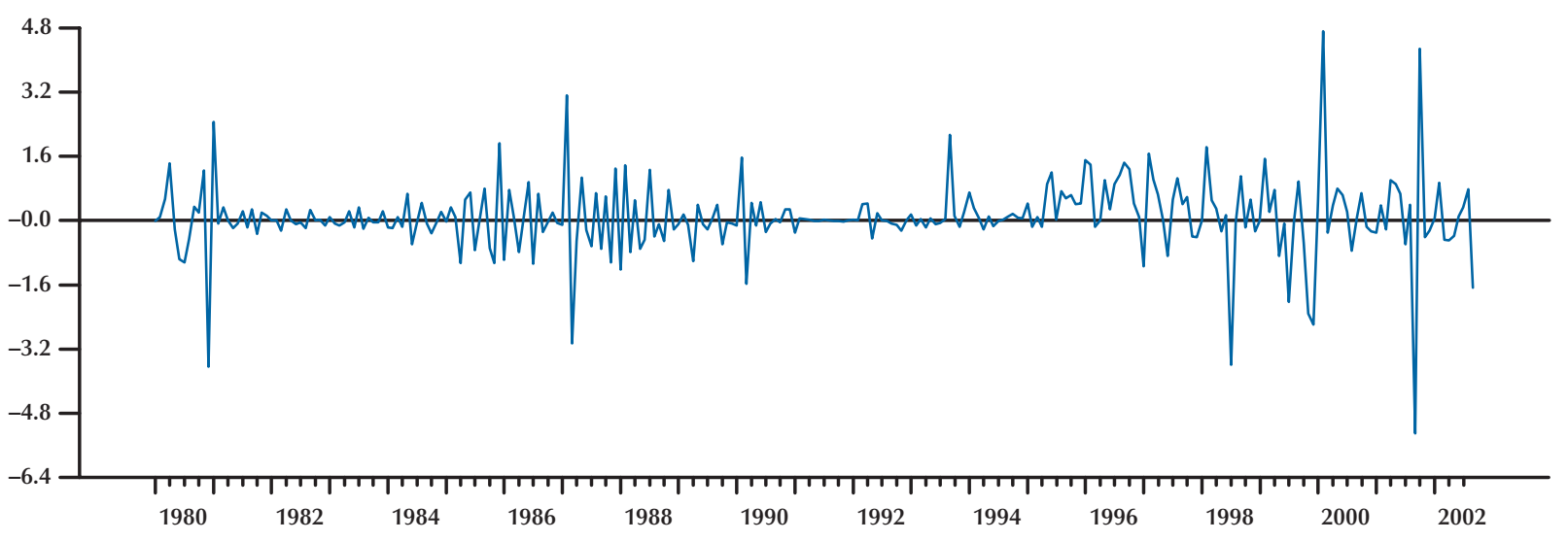




\section{REFERENCES}

Anderson, Richard G. "Retail Sweep Programs and Money Demand.” Federal Reserve Bank of St. Louis Monetary Trends, November 2002.

and Kavajecz, Kenneth J. "A Historical

Perspective on the Federal Reserve's Monetary Aggregates: Definition, Construction and Targeting." Federal Reserve Bank of St. Louis Review, March/April 1994, 76(2), pp. 1-31.

and Rasche, Robert H. "Measuring the Adjusted Monetary Base in an Era of Financial Change." Federal Reserve Bank of St. Louis Review, November/December 1996, 78(6) pp. 3-37.

and "Eighty Years of Observations on the Adjusted Monetary Base: 1918-1997." Federal Reserve Bank of St. Louis Review, January/February 1999, 81(1), pp. 3-22.

and "The Domestic Adjusted

Monetary Base.” Working Paper 2000-02A, Research Division, Federal Reserve Bank of St. Louis.

and "Retail Sweep Programs and Bank Reserves, 1994-1999." Federal Reserve Bank of St. Louis Review, January/February 2001, 83(1), pp. 51-72.

Board of Governors of the Federal Reserve System. Banking and Monetary Statistics, 1914-1941. Washington, DC: Board of Governors of the Federal Reserve System, 1943 [reprinted 1976].

Banking and Monetary Statistics 1941-1970.

Washington, DC: Board of Governors of the Federal Reserve System, 1976.

Annual Report. Washington, DC: Board of Governors of the Federal Reserve System, various issues.

Annual Statistical Digest. Washington, DC:

Board of Governors of the Federal Reserve System, various issues.

Federal Reserve Bulletin. Washington, DC: Board of Governors of the Federal Reserve System, various issues.

Brunner, Karl and Meltzer, Allan H. "The Place of Financial Intermediaries in the Transmission of Monetary Policy." American Economic Review, May 1963, 53(2), pp. 372-82. and "Liquidity Traps for Money, Bank Credit and Interest Rates." Journal of Political Economy, January/February 1968, 76(1), pp. 1-37.

Burger, Albert E. and Rasche, Robert H. "Revision of the Monetary Base." Federal Reserve Bank of St. Louis Review, July $1977,59(7)$, pp. 13-28.

Findley, David F.; Monsell, Brian C.; Bell, William R.; Otto, Mark C. and Chen, Bor-Chung. "New Capabilities and Methods of the X-12-ARIMA Seasonal-Adjustment Program." Journal of Business and Economic Statistics, April 1998, 16(2), pp. 127-52.

Friedman, Milton and Jacobson Schwartz, Anna. A Monetary History of the United States, 1867-1960. Princeton: Princeton University Press, 1963.

and Monetary Statistics of the

United States: Estimates, Sources, and Methods. New York: National Bureau of Economic Research, 1970.

and Monetary Trends in the United States and the United Kingdom: Their Relations to Income, Prices, and Interest Rates, 1876-1975. Chicago: University of Chicago Press, 1982.

McCallum, Bennett T. "Specification and Analysis of a Monetary Policy Rule for Japan." Monetary and Economic Studies, November 1993, 11(2), pp. 1-45.

"Monetary Policy Analysis in Models without Money." Federal Reserve Bank of St. Louis Review, July/August 2001, 83(4), pp. 145-60.

“Japanese Monetary Policy, 1991-2001."

Federal Reserve Bank of Richmond Economic Quarterly, Winter 2003, 89(1), pp. 1-31.

Meltzer, Allan H. "The Transmission Process," in The Monetary Transmission Process: Recent Developments and Lessons for Europe. New York: Palgrave/Deutsche Bundesbank, 2001a, pp. 112-30.

"Monetary Transmission at Low Inflation: Some Clues from Japan in the 1990s." Monetary and Economic Studies, February 2001b, 19(Special Edition), pp. 1-34.

A History of the Federal Reserve. Vol. 1, 19131951. Chicago: University of Chicago Press, 2003. 
Nelson, Edward. "Direct Effects of Base Money on Aggregate Demand: Theory and Evidence." Journal of Monetary Economics, May 2002a, 49(4), pp. 687-708.

"The Future of Monetary Aggregates in Monetary Policy Analysis." Presented at the CarnegieRochester Conference on Public Policy, 22-23 November 2002b (forthcoming in Journal of Monetary Economics, July 2003).

Sargent, Thomas J. Macroeconomic Theory. London: Harcourt Brace Jovanovich, 1987.
Tatom, John A. "Issues in Measuring an Adjusted Monetary Base." Federal Reserve Bank of St. Louis Review, December 1980, 62(10), pp. 11-29.

Taylor, John B. "Discretion versus Policy Rules in Practice." Carnegie-Rochester Conference Series on Public Policy, December 1993, 39(0), pp. 195-214.

\section{Appendix}

\section{NOTES ON DATA SOURCES AND CALCULATION OF THE SOURCE BASE AND RAM}

\section{The Monetary (Source) Base}

The Federal Reserve Bank of St. Louis monetary (source) base is defined as those liabilities of the monetary authorities (U.S. Treasury and the Federal Reserve) that (i) the nonbank public uses as media of exchange and (ii) depository institutions use to satisfy statutory reserve requirements and/or to settle interbank debts (such as clearing checks or transferring funds by wire).

We measure the monetary base, monthly and biweekly, as the average daily level of (i) currency in circulation outside the Treasury and Federal Reserve Banks, plus (ii) the deposits held by depository institutions at the Federal Reserve Banks. Monthly observations on the Federal Reserve Bank of St. Louis monetary base are available beginning December 1917, and biweekly observations are available beginning with the reserve maintenance period that ended February 15, 1984. (This is the first two-week "reserve maintenance period" under the system of statutory reserve requirements adopted by the Board of Governors as of February 2 , 1984.)

Currency in Circulation. For monthly figures, our sources are as follows:

- December 1917-December 1958: Figures through 1941 are from Banking and Monetary Statistics, 1914-1941 (Board of Governors, 1943 [reprinted 1976], Table 101, pp. 369-71, the column "Money in circulation"). Later figures are from Banking and Monetary Statistics, 1941-1970 (Board of Governors, 1976, Table 10.1B, pp. 526-35, the column "Currency in circulation").

- January 1959 to date: Banking and Monetary Statistics, 1941-1970 (noted above), various issues of the Annual Statistical Digest, the Board of Governors H.4.1 release ( < www.federalreserve.gov/releases/h41/>), and the Federal Reserve Bulletin (January 2003, Table 1.11, p. A5, line 17).

For biweekly figures, we use arithmetic averages of weekly averages of daily figures. For weekly figures beginning February 1984, our sources are as follows:

- Weeks ending February 15, 1984-December 26, 1984: Annual Statistical Digest 1984 (Board of Governors, October 1985, Table 2.B, pp. 7-9, line 15, "Currency in circulation").

- Weeks ending January 2, 1985-December 25, 1985: Annual Statistical Digest 1985 (Board of Governors, October 1986, Table 2.B, pp. 7-9, line 15, "Currency in circulation").

- January 1986 to date: Annual Statistical Digest, the Board of Governors H.4.1 release (<www.federalreserve.gov/releases/h41/>), and the Federal Reserve Bulletin (January 2003, Table 1.11, p. A5, line 17).

Federal Reserve Bank Deposits. Although the Board of Governors has collected daily balancesheet figures from each Reserve Bank since the beginning of the System, the Board has not, and 
does not, publish monthly or weekly averages of these figures. ${ }^{32}$ Rather, only Wednesday and endof-month figures are published. Ideally, if these figures were available, we would measure the monetary base as period averages of the deposits of depository institutions at the Reserve Banks (Federal Reserve Bulletin, January 2003, Table 1.18, p. A10, line 25). Instead, we measure the monetary base by the sum of "reserve balances at the Reserve Banks" (Federal Reserve Bulletin, January 2003, Table 1.11, p. A5, line 25) plus, beginning August 1981, "service-related balances and adjustments" (Federal Reserve Bulletin, January 2003, Table 1.11, p. A5, line 22). From an accounting viewpoint, the latter item was zero prior to implementation of the Monetary Control Act in November 1980 and, hence, reserve balances differed from member bank deposits at the Federal Reserve only by a variety of accounting adjustments related to check processing and other financial services. We acknowledge that for some early years this measure omits certain small deposit amounts held at the Reserve Banks by nonmember institutions for settling interbank payments (as described by Friedman and Schwartz, 1963, p. 748). Beginning August 1981 with the first published figures on service-related balances, in the Annual Statistical Digest, reserve balances excludes an amount of deposits at the Federal Reserve equal to the nominal amount of depository institutions' required clearing balance contracts; for details, see Anderson and Rasche (1996a).

The first published monthly average figures for member bank reserves are for August 1917. The St. Louis measures of the adjusted monetary base and adjusted reserves begin in December 1917 because that is the first month deposit figures permit calculation of RAM.

For monthly figures, our sources are as follows:

- December 1917-December 1970: Figures through 1941 are from Banking and Monetary Statistics, 1914-1941 (Board of Governors, 1943 [reprinted 1976], Table 101, pp. 369-71, the column "Member bank reserve balances, Total”). Later figures are from Banking and Monetary Statistics, 1941-1970 (Board of

\footnotetext{
32 The report that collects these daily figures is referred to within the Federal Reserve as the FR34 report. Wednesday and end-of-month figures are published as the condition statement of the Federal Reserve Banks (Federal Reserve Bulletin, January 2003, Table 1.18, p. A10).
}

Governors, 1976, Table 10.1B, pp. 526-29, the column "Member bank reserves, Total" and pp. 530-35, the column "Member bank reserves, with F.R. Banks"). Except for small accounting adjustments, these figures equal the deposits held by member banks at Federal Reserve Banks. So far as we are aware, these volumes are the only source for monthly averages of daily deposits at the Federal Reserve Banks.

- January 1970-December 1979: Annual Statistical Digest, 1970-1979 (Board of Governors, March 1981, Table 2.A, pp. 10-15, row 21, "Member bank reserves with Federal Reserve Banks").

- January 1980-December 1989: Annual Statistical Digest 1980-1989 (Board of Governors, 1991, Table 2.A, pp. 11-20, the sum of line 23, "Reserve balances with Federal Reserve Banks," plus line 19, "Service-related balances and adjustments," plus line 21, "Required clearing balances"). Note that the required clearing balance figures reported for 1981-83 include adjustments; that is, although not labeled as such, the figures are the sum of service-related balances and adjustments.

- January 1990-December 1990: Annual Statistical Digest, 1990-1995 (Board of Governors, November 1996, Table 2, p. 7 , the sum of line 22, "Reserve balances with Federal Reserve Banks," and line 19, "Servicerelated balances and adjustments").

- January 1991 to date: Board of Governors H.4.1 release and Table 1.18 of the Federal Reserve Bulletin. These figures are the sum of reserve balances plus service-related balances and adjustments.

- For biweekly figures, our sources are the Board of Governors Annual Statistical Digest issues from 1984 through 1990 and the H.4.1 release thereafter. Where necessary, biweekly figures are arithmetic averages of weekly figures.

\section{The Reserve Adjustment Magnitude (RAM)}

- December 1917-August 1935. During this period, the primary change to the Federal Reserve's statutory reserve requirements was the reclassification in 1922 of St. Louis 
from a central reserve city to a reserve city. This change had been proposed by large St. Louis banks to reduce their required reserves. Our RAM calculation is based on figures from the Federal Reserve Bulletin regarding net demand deposits at weekly reporting member banks in the city of St. Louis. A second major change in reserve requirements occurred in August 1935, when the Banking Act of 1935 changed the calculation (definition) of net demand deposits and made U.S. government deposits subject to the same reserve requirements as applied to private deposits. For further details, see Anderson and Rasche (1999).

- August 1935-August 1968. Reserve requirements changed little during this period prior to 1966 . Through June 1966, separate reserve-requirement ratios applied to net demand deposits classified by location (central reserve city, reserve city, and country), and a single ratio applied to all time (including saving) deposits. Beginning July 1966, the reserve-requirement distinction between central reserve city and reserve city banks was discontinued. In addition, time deposits became subject to reserverequirement ratios that differed based on a bank's aggregate time deposits. Our RAM construction uses deposit figures and reserverequirement ratios from Tables 10.3 and 10.4 in Banking and Monetary Statistics, 1941 1970. Beginning July 1966, for time deposits, we use unpublished figures from the archives of the St. Louis Fed's Research Division. ${ }^{33}$ We measure $R A M^{\text {deposits }}$ as the difference between a counterfactual required-reserve figure calculated from the Banking and Monetary Statistics deposit figures and the reserve-requirement regime in effect during September 1935, minus the level of required reserves that we calculate from the Banking and Monetary Statistics deposit figures. ${ }^{34}$ Note that $R A M_{1935}^{\text {deposits }}$ is zero

\footnotetext{
33 Different requirement ratios are applied to a bank's total time (and savings) deposits under $\$ 5$ million compared with over $\$ 5$ million. Aggregate time deposits in these categories, aggregated across banks, are unpublished figures.

34 From January 1936 through December 1967, our calculated requiredreserve figures differ from the Banking and Monetary Statistics published figures by no more than two or three thousand dollars, except for June 1966. In that month, the published and calculated
}

for August 1935-July 1936. For all months in this segment, $R A M_{1935}^{\text {other }}$ is equal to zero.

- September 1968-December 1972. Beginning September 12, 1968, banks' weekly required reserves were computed on the basis of average daily deposits held two weeks earlier. In our calculation of $R A M_{1935}^{\text {deposits }}$, we apply the 1935 reserve-requirement ratios to monthly averages of lagged weekly deposits even though the 1935 regime (our "base period" for RAM) has contemporaneous requirements. Our monthly average figures for deposits subject to reserve requirements are pro rata averages of (lagged) weekly deposit figures from the Board of Governors J.1 and H.7 statistical release, supplemented by data from the archives of the St. Louis Fed's Research Division.

- December 1972-January 1975. Beginning November 9, 1972, the reserve-requirement distinction for demand deposits between reserve city and country banks was removed. In its place, demand deposits became subject to a system of tiered, graduated requirements. On the same date, the system of graduated requirements on time deposits was extended such that the applicable ratios varied both with the bank's aggregate timedeposit liabilities and with the remaining time to maturity of each deposit. 35 During this period, the Board of Governors expanded its practice of imposing special and marginal reserve requirements (see Table 3). ${ }^{36}$ Our monthly deposit figures, constructed as pro rata averages of lagged weekly figures, are from the archives of the St. Louis Fed's Research Division. For the part of required reserves that may be calculated from aggregate monthly deposit figures, $R A M_{1972}^{\text {deposits }}$ varies from zero (the value for

values are $\$ 22.212$ billion and $\$ 22.201$ billion, respectively. We use the calculated values in measuring RAM. The Board of Governors has published revised total required reserves.

${ }^{35}$ Burger and Rasche (1977) discuss the impact of these changes on (a previous version of) RAM. Despite the technical change in require ments on time deposits that permitted varying the graduated reserverequirement ratios by remaining maturity, ratios prior to December 1974 differed only by a bank's aggregate time deposits-with a 3 percent ratio applying up to $\$ 5$ million and 5 percent thereafter.

36

Historically, a supplemental requirement was one imposed on a deposit or other liability that had not previously been subject to a requirement. A "marginal" requirement was a surcharge imposed in addition to a preexisting regular requirement 
each month from December 1972 through June 1973) to a low of $-\$ 715$ million in January 1974 , with a mean value of $-\$ 421$ million. For the remainder of required reserves (largely due to special and marginal reserve requirements), $R A M_{1972}^{\text {other }}$ ranges from near zero during the early months of the interval to a low of approximately $-\$ 1.5$ billion during August and September 1974. Total RAM peaks at $-\$ 2.2$ billion in September 1974 and averages approximately $-\$ 1.1$ billion.

- January 1975-October 1980. Beginning December 12, 1974, requirements on time deposits were changed such that only reserve-requirement ratios on deposits with remaining time-to-maturity of 30 to 179 days varied with the amount of the bank's aggregate time-deposit liabilities. As above, monthly average deposit figures are constructed from the archives of the St. Louis Fed's Research Division. RAM deposits is positive for all months after January 1975 , beginning with mid-February's approximately $\$ 1$ billion reduction in required reserves, and averages approximately $\$ 2.4$ billion. During the early part of the period, through October 1978, RAM 1975 is positive and averages approximately $\$ 225$ million. With the imposition of supplementary reserve requirements on large time deposits in November 1978, $R A M_{1975}^{\text {other }}$ becomes sharply negative, averaging $-\$ 2.7$ billion during the next 21 months (the requirement was removed in July 1980). Total RAM ranges from a high of $\$ 3.4$ billion to a low of $-\$ 1.5$ billion and averages $\$ 1.7$ billion over the period.

- November 1980-September 2002. During this period, for months prior to January 1991, RAM is unchanged. Beginning January 1991 through December 1993, RAM is an updated version, to incorporate revised data, of that proposed in Anderson and Rasche (1996). Beginning January 1994, RAM is an updated version of the "preferred" RAM adjustment shown as line "1" in Figure 10 of Anderson and Rasche (2001). This adjustment regards a bank's implementation of a retail-deposit sweep program as economically equivalent to a reduction in the applicable reserverequirement ratio for transaction deposits. ${ }^{37}$

37 This RAM uses as its base period the reserve-requirement regime that became effective for weekly reporting banks on December 27 , 1990 (the reserve maintenance period ending January 7, 1991). 
Anderson, Rasche, Loesel 